\title{
20. OPTICAL ANALYSIS OF THE ORGANIC AND INORGANIC CONSTITUENTS OF THE PALYNOLOGICAL RESIDUE IN SEDIMENTS FROM THE MOUTH OF THE GULF OF CALIFORNIA AND GUAYMAS BASIN, DEEP SEA DRILLING PROJECT LEG 64: SEDIMENTOLOGICAL AND DIAGENETIC IMPLICATIONS ${ }^{1}$
}

\author{
Jaime Rueda-Gaxiola, Julio Morales, and Marco Antonio Dueñas, Instituto Mexicano del Petróleo, \\ México, D.F., México
}

\begin{abstract}
This chapter presents a palynological analysis of 74 samples of sediments from 66 cores collected from Holes 474 , 474A, 475, and 476, in the mouth of the Gulf of California, and Holes 477, 477A, and 478, in the Guaymas Basin. Palynological-stratigraphic analysis of sediments was undertaken to determine biostratigraphic facies distribution, diagenesis of organic matter, type and origin of sedimentary organic matter, heat flow effects on the organic matter, and the effects of intrusion events upon sediments. Slides prepared with both total and traditional (refractive) palynological residues were subjected to optical analysis.

Determination of sedimentary environments was based both on analysis of the physical characteristics of the detrital organic and inorganic products and on micropaleontological analysis of organic remains in the residue.
\end{abstract}

\section{INTRODUCTION}

This chapter reports the results of a palynological analysis of sediments from Holes 474-478, Leg 64.

Holes 474-476 are in the mouth of the Gulf of California, from the crest of the East Pacific Rise where rapid sea-floor spreading is occurring to the young passive margin at the tip of Baja California. Holes 477-478 are in the Guaymas Basin in the central Gulf. In drilling at these sites we hoped to answer fundamental questions regarding the early stages of the formation of ocean basins and passive continental margins and the effect of rapid terrigenous sedimentation on crustal formation and hydrothermal circulation at a young, divergent plate boundary (see site chapters, this volume, Pt. 1).

In drilling Holes 474-476, we planned to study the early drifting history at the mouth of the Gulf of California. The Guaymas Basin (Holes 477-478) includes two segments of a spreading axis separated by a short transform fault and flanked by long transform faults that presumably separate the ocean crust created during the present phase of opening of the Gulf from either continental crust or proto-Gulf (see site chapters, background and objectives sections, this volume, Pt. 1). Heat flow in the Guaymas Basin is high within the rifts and sediment accumulation is higher than in the mouth of the Gulf. The sedimentary column includes several igneous rock layers and is affected by hydrothermal activity. These characteristics make the mouth of the Gulf and the Guaymas Basin two very interesting areas in which palynological analysis of sediments may help to determine biostratigraphic facies distribution, the diagenesis of organic matter, the type and origin of sedimentary

\footnotetext{
${ }^{1}$ Curray, J. R., Moore, D. G., et al., Init. Repts. DSDP, 64: Washington (U.S. Govt. Printing Office).
}

organic matter and the high heat flow effects upon it, and the effect of intrusion events upon the sediments.

To achieve some of these objectives it was necessary to apply a new palyno-stratigraphic method, developed at the Instituto Mexicano del Petróleo and based on the analysis of the entire palynological residue $(\mathrm{HCl} / \mathrm{HF}$ insoluble detritus) plus computer plotting of the data that enabled us to determine zones of various parameters in the sedimentary section.

This palyno-stratigraphic method has previously proved useful in evaluating petroleum basins (RuedaGaxiola, 1975, 1978; Rueda-Gaxiola, et al., 1977, 1980) because it makes it possible to define sedimentary environments over time and distance and also to determine the oil and gas production potential of different lithostratigraphic units. In petroleum basins, relatively old rocks - only rarely unconsolidated sediments-are the subject of analysis. This study for the first time uses this method in the analysis of very young marine sedimentary sequences to provide results that can be compared with those from petroleum basins.

Determination of the sedimentary environment is based upon analysis of the physical characteristics of detrital organic and inorganic products and on paleontological analysis of organic remains of plants and animals in the residues.

The physical characteristics of the detritus which indicate sedimentary conditions are abundance, aspect, and color of the palynological residue; abundances of the mineral and organic matter; presence of pyrite; and size of terrestrial minerals, crystalline fragments, amorphous mineral matter, and particles of organic matter.

Paleontological analysis of organic matter in residues includes determination of type and color, maturation indices, and quantity and quality of palynomorphs (a study not undertaken here). 
Finally, the procedure included color determination of the glycerin-alcohol solution in which the residue was maintained.

Traditional palynologic methods have been successfully applied at different sites to determine the source and distribution of palynomorphs from the sea bottom and from deeper sediments in relation to environment (Müller, 1959; Cross et al., 1966; Traverse et al., 1966; and Manum, 1976, among others). Cross et al. (1966) analyzed 120 bottom-sediment samples from locations along 9 transects across the southern part of the Gulf of California and plotted the results to show the geographic distribution of pollen and spores, their absolute frequency in grains/g sediment, abundance of cuticles and tracheids, abundance of dinoflagellates and microforaminifers in relation to bathymetry, and wind and sedimentation patterns.

\section{MATERIALS AND METHODS}

One hundred and forty samples collected aboard ship were macerated, and 74 of them, from 66 cores, were selected for analysis: 21 from Holes 474 and 474A, 7 from Hole 475, 9 from Hole 476, 23 from Holes 477 and $477 \mathrm{~A}$, and 14 from Hole 478 . The depth distribution of these samples is shown in Table 1 .

Samples were selected on the basis of depth. When possible-and to represent a continuous lithology-we selected those samples separated by less than 50 meters of sediment. In some cases, we used the available samples even if they were separated by more than 50 meters.

For each sample, two slides were prepared for each of three different analyses: (1) smear slides; (2) total palynological residue; (3) refractive palynological residue (in every case, one of the two slides was stained with Safranin to distinguish between organic and inorganic matter).

To obtain the two kinds of residue, $10 \mathrm{~g}$ of each sample were macerated by two successive chemical methods as follows:

1) First, mineral matter was dissolved in hydrochloric and then hydrofluoric acid. In this way, we recovered the total palynological residue composed of residual mineral matter and nonoxidized organic matter (kerogen or $\mathrm{HCl} / \mathrm{HF}$ insoluble detritus).

2) After the mineral matter was dissolved, a portion of the residue was treated with nitric acid and potassium chlorate to oxidize and remove the humic material. This represents the refractive palynological residue; it is composed almost completely of concentrated palynomorphs.

Comparative optical analysis of the three types of slides permitted us to observe how the acids dissolved the components of the sediment analyzed in the smear slides.

Because the results of the optical analysis were to be statistically analyzed, it was necessary to prepare uniform slides with the same quantities of residue and gelatine and to count all palynomorphs on the surface of the slide; 336 slides were thus analyzed, and the results for each characteristic of the components of the residue were plotted on the computer and vertically graphed as polygons with total values. The data used in generating these graphs correspond almost completely to those resulting from kerogen slide analysis, in that they represent the organic residue with a minimum of alteration. Furthermore, some minerals dissolved by the nitric acid are still present in these slides and can be determined and quantitated.

Figures 1-3 show the vertical variation of selected characteristics for samples analyzed from each hole.

\section{ABUNDANCE OF PALYNOLOGICAL RESIDUE}

The relative abundance of the palynological residue was measured by its height (in $\mathrm{mm}$ ) in the vial in which it was maintained. To keep the residue from becoming dry, it was preserved in a glycerin-alcohol solution. The height of the residue in the vial is a value proportional to its real abundance in $10 \mathrm{~g}$ of sediment. The height is neither a volumetric abundance nor a weight value.
Table 1. Depth distribution of the samples analyzed, Leg 64.

\begin{tabular}{|c|c|}
\hline $\begin{array}{c}\text { Sample } \\
\text { (interval in } \mathrm{cm} \text { ) }\end{array}$ & $\begin{array}{c}\text { Depth } \\
\text { (m) }\end{array}$ \\
\hline $474-1-1,40-42$ & 0.42 \\
\hline $474-5-4,40-45$ & 35.45 \\
\hline $474-8-5,66-71$ & 65.71 \\
\hline $474-12-1,13-17$ & 97.17 \\
\hline $474-18-2,119-124$ & 156.74 \\
\hline $474 \mathrm{~A}-3-5,120-125$ & 189.75 \\
\hline $474 A-6-2,84-86$ & 213.36 \\
\hline $474 \mathrm{~A}-9-4,108-113$ & 245.13 \\
\hline $474 \mathrm{~A}-13-4,85-90$ & 282.85 \\
\hline $474 \mathrm{~A}-17-3,122-124$ & 319.74 \\
\hline $474 \mathrm{~A}-21-3,90-95$ & 347.95 \\
\hline $474 \mathrm{~A}-25-1,3-8$ & 382.08 \\
\hline $474 \mathrm{~A}-30-2,16-18$ & 431.18 \\
\hline $474 \mathrm{~A}-33-2,103-108$ & 460.58 \\
\hline $474 \mathrm{~A}-36-1,70-72$ & 486.77 \\
\hline $474 \mathrm{~A}-36-1,73$ & 486.83 \\
\hline $474 \mathrm{~A}-37-1,1-8$ & 496.08 \\
\hline $474 \mathrm{~A}-39-3,60-65$ & 518.65 \\
\hline $474 \mathrm{~A}-40-3,21-24$ & 527.74 \\
\hline $474 \mathrm{~A}-41-1,78-79$ & 534.79 \\
\hline $474 \mathrm{~A}-41-5,11$ & 541.21 \\
\hline $475-2-4,99-101$ & 11.51 \\
\hline $475-5-4,50-54$ & 39.54 \\
\hline $475-9-4,93-95$ & 77.95 \\
\hline $475-12-4,109-114$ & 106.64 \\
\hline $475-15-1,80-84$ & 130.34 \\
\hline $475-17-5,7-9$ & 154 \\
\hline $475-17-2,20-25$ & 150.25 \\
\hline $476-1-2,102-104$ & 2.54 \\
\hline $476-5-4,54-56$ & 42.56 \\
\hline , $137-141$ & 90.91 \\
\hline $476-15-3,15-17$ & 135.67 \\
\hline $476-18-4,60-65$ & 166.15 \\
\hline $476-20-4,56-60$ & 185.10 \\
\hline $476-21-4,9-11$ & 194.11 \\
\hline $476-21, C C$ & 198.50 \\
\hline $476-26-1,45-47$ & 237.97 \\
\hline $477-2-4,25-27$ & 5.77 \\
\hline $477-3-1,5-7$ & 10.57 \\
\hline $477-3-2,61-63$ & 12.63 \\
\hline $477-3-2,59-64$ & 12.64 \\
\hline $477-4-1,77-79$ & 20.79 \\
\hline $477-5-1,62-67$ & 25.17 \\
\hline $477-5-2,127-129$ & 27.29 \\
\hline $477-7-1,52-54$ & 49.04 \\
\hline $477-15-1,0-2$ & 105.52 \\
\hline $477-15-1,61-65$ & 106.15 \\
\hline $477-16-3,72-74$ & 118.74 \\
\hline $477-17-2,75-80$ & 126.80 \\
\hline $477-19-2,37-42$ & 145.42 \\
\hline $477-20-1,35-40$ & 172.40 \\
\hline $477-22-1,35-40$ & 172.40 \\
\hline $477-23-1,30-32$ & 191.00 \\
\hline $477 \mathrm{~A}-5-1,120-1$ & 192.22 \\
\hline $477 \mathrm{~A}-6, \mathrm{CC}$ & 209.90 \\
\hline $477 \mathrm{~A}-7-1,56-61$ & 210.61 \\
\hline $477 \mathrm{~A}-8, \mathrm{CC}$ & 229.00 \\
\hline $477 \mathrm{~A}-9-1,11-$ & 229.16 \\
\hline $477 \mathrm{~A}-10-1,70-75$ & 239.25 \\
\hline $477 \mathrm{~A}-11-1,30-40$ & 248.40 \\
\hline $478-1-1,33-35$ & 0.35 \\
\hline $478-3-3,127-12$ & 17.29 \\
\hline $478-6-5,1-6$ & 47.56 \\
\hline $478-9-4,114$ & 75.67 \\
\hline $478-11-2,57-59$ & 91.09 \\
\hline $478-14-3,54-58$ & 121.08 \\
\hline $478-17-3,81-86$ & 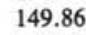 \\
\hline $478-22-1,57-59$ & 184 \\
\hline $478-29-1,91-93$ & 251.43 \\
\hline $478-32-3,11-116$ & 273.66 \\
\hline $478-35-3,58-60$ & 301.60 \\
\hline $478-36-3,101-106$ & 311.56 \\
\hline $478-39-3,18-20$ & 329.70 \\
\hline $478-40-2,55-57$ & 338.07 \\
\hline
\end{tabular}


The computer graphs include not only the values measured for residues from selected samples but also those of the samples not considered in the palynological analysis. Figures 1-3 show the vertical variation in the abundance of the residue compared with the lithologic column for each hole. These graphs show that distribution is related to lithology and to the geographical position of the hole. In general, we observed higher values in the sediments from Holes 474-476 and lower values in Holes 477-478. In particular, the highest values are in samples with a very fine lithology-hemipelagic diatomaceous and nannofossil oozes and muds. The lowest values belong to coarse sediments-arkoses and sandy turbidites.

\section{Mouth of the Gulf (Fig. 4)}

Holes 474 and $474 \mathrm{~A}$. Unit II is composed of redeposited diatomaceous muds and marls, and the relative abundance of the residue exceeds $5 \mathrm{~mm}$; a maximum of $15 \mathrm{~mm}$ is reached in Core $474-5(35.45 \mathrm{~m})$ and a minimum $(<5 \mathrm{~mm})$ in coarse arkose, Core 474-8 $(65.71 \mathrm{~m})$. Unit III, composed of mud turbidites and olive gray silty clay, contains more than $5 \mathrm{~mm}$ of residue; a maximum $(>15 \mathrm{~mm})$ is reached in Core 474-18 $(156.74 \mathrm{~m})$. In Unit IV, composed of mud turbidites and olive gray silty claystone to clayey siltstone, the residue content is higher than $5 \mathrm{~mm}$ and the maximum value of $15 \mathrm{~mm}$ is reached in Core 474A-9 $(245.13 \mathrm{~m})$. Finally, Unit V, above the dolerite sill and composed of clayey siltstone, sands, mudflows, and turbidites, also contains more than $5 \mathrm{~mm}$ of residue; a maximum of $15 \mathrm{~mm}$ is reached in Core 474A-39 $(518.65 \mathrm{~m})$.

Hole 475. Unit I is composed of hemipelagic, olive brown diatomaceous muds, Unit II of hemipelagic muds, and Unit III of diatomaceous muds. Sediments generally contain residues with values higher than $10 \mathrm{~mm}$; a maximum of $30 \mathrm{~mm}$ is reached at the contact between Units I and II (39.54 m).

Hole 476. Values higher than $5 \mathrm{~mm}$, with a maximum at Core $476(65 \mathrm{~m})$, were found. Units I and II are composed, respectively, of hemipelagic diatomaceous and nannoplankton ooze and mud.

\section{Guaymas Basin (Fig. 4)}

In the Guaymas Basin, the residue content of sediments in Holes $477-478$ is in general lower than in the mouth of the Gulf.

Holes 477 and $477 A$. The unit above the dolerite sill (Cores 477-1-7) consists of olive brown diatomaceous ooze and turbiditic material; a maximum $(29 \mathrm{~mm})$ is reached in Core 477-3 (12.63 m). Unit II beneath the sill (Cores $477-15-23$ and $477 \mathrm{~A}-4-12$ ) is characterized by residue values lower than $10 \mathrm{~mm}$. A maximum $(15 \mathrm{~mm})$ is reached in Core 477A-10 (239.25 m). This unit, composed of hydrothermally altered terrigenous turbidites and muds, shows very low values-less than $5 \mathrm{~mm}$ in Cores 477-16 (118.74 m), 477A-5 (192.22 m), and 477A-6 $(209.90 \mathrm{~m})$.

Hole 478. The unit above the dolerite sills is composed of olive brown diatomaceous ooze and gray sandy turbidites. Values are generally lower than $5 \mathrm{~mm}$. A maximum of $10 \mathrm{~mm}$ is reached in Core 478-11 (91.09 $\mathrm{m})$. The unit beneath the dolerite sills, composed of diatom mudstones, is characterized by a gradual decrease in the content of palynological residue, from $10 \mathrm{~mm}$ beneath the dolerite sills to less than $5 \mathrm{~mm}$ at the bottom of the hole.

\section{COLOR OF THE RESIDUE}

The color of the palynological residue depends on the variety and quantity of its mineral and organic components, which in turn reflect the types of materials present in the sediments. Therefore, this color can be related to sedimentary and diagenetic effects (see Figs. $1-3$, which correlate color with lithology, maturation indices, and other characteristics, for each hole).

Residues are classified according to 12 basic colors and 27 different color degrees by a system developed in the palynological laboratory of the Instituto Mexicano del Petróleo. The 12 basic colors are (1) white; (2) pale yellow; (3) orange; (4) violet brown; (5) reddish brown; (6) purple brown; (7) sepia brown; (8) light brown; (9) lead gray; (10) gray; (11) dark gray; (12) black.

\section{Mouth of the Gulf (Fig. 5)}

In all holes the residue is black in the lithological units composed of hemipelagic muds, silty claystone, and clayey siltstone materials. Only one sample was taken from a unit composed of conglomerates (Unit V, Core 476-26, $237.97 \mathrm{~m}$ ); it is composed of gray sandy clay, possibly with an atmospheric exposure. In all samples the color of the residue is related to high organic matter and low mineral matter abundance.

A light brown color appears in the coarse arkose sediments of Unit II in Hole 474A. In Hole 476, at the contact between Units III and IV (Core 476-20, $185.10 \mathrm{~m}$ ), this color occurs in sediments with glauconitic sands. In Core 475-12 (Unit II, $106.64 \mathrm{~m}$ ), light brown occurs in a sample taken from a thin layer of hemipelagic sediment, also containing glauconitic material.

\section{Guaymas Basin (Fig. 5)}

Here, the black color of the residue seems related to the presence and type of coaly organic debris and also of abundant organic matter in fine-grained sediments. For instance, in Units I and II of Holes 477 and 477A, the residue is black; at the top of the units light brown, dark gray, and gray occur. These dark colors correlate almost directly with the graphs depicting the presence of coaly matter and with a high maturation index. As we will describe later, the abundance of coaly debris is due to the influence of a high geothermal gradient and to the presence of dolerite sills in the sedimentary section. We will return to this issue also in discussing the maturation index of the organic matter.

In the residues from Hole 478, we also found also a rough correlation between color and the presence, type, and maturation of organic matter. At the top of Unit I, however, values of residue coloration are low. At the bottom of this unit there are no particles of coaly matter but the algal detritus is black, possibly as a result of the thermal effect of the dolerite sills. Beneath these sills the 


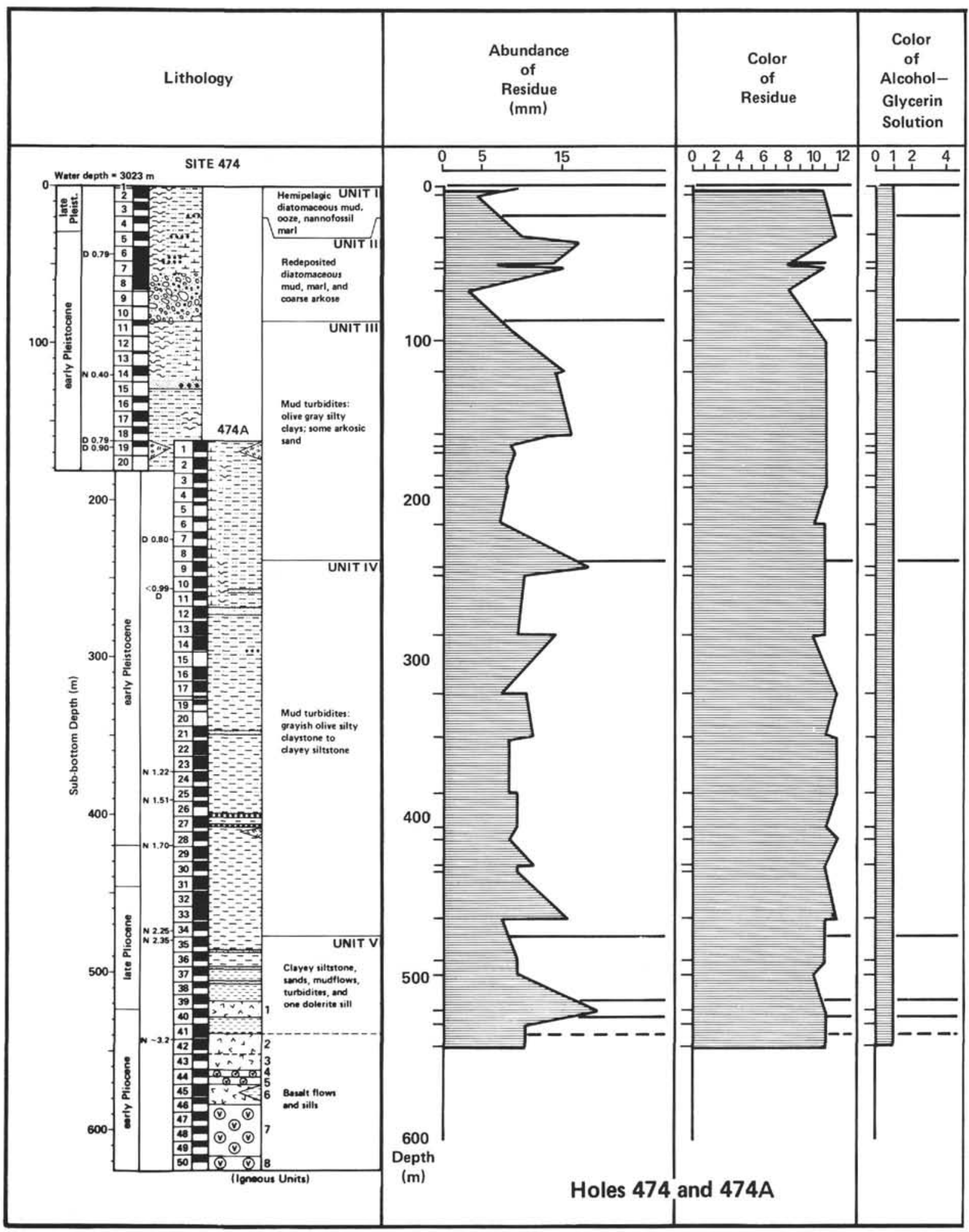

Figure 1. Vertical variation in selected characteristics of the palynological residue, Holes 474 and 474A. [Open areas: distance between two successive samples between 50 and $25 \mathrm{~m}$; ruled areas: this distance is $<25 \mathrm{~m}$. Color of the residue is graded as follows: (1) white; (2) pale yellow; (3) orange; (4) violet brown; (5) reddish brown; (6) purple brown; (7) sepia brown; (8) light brown; (9) lead gray; (10) gray; (11) dark gray; (12) black. Color of the alcohol-glycerin solution is graded as follows: (1) colorless and white; (2) yellow; (3) greenish yellow; (4) light yellow. Residue type is defined as (1) "irregular; (2) "regular."] 


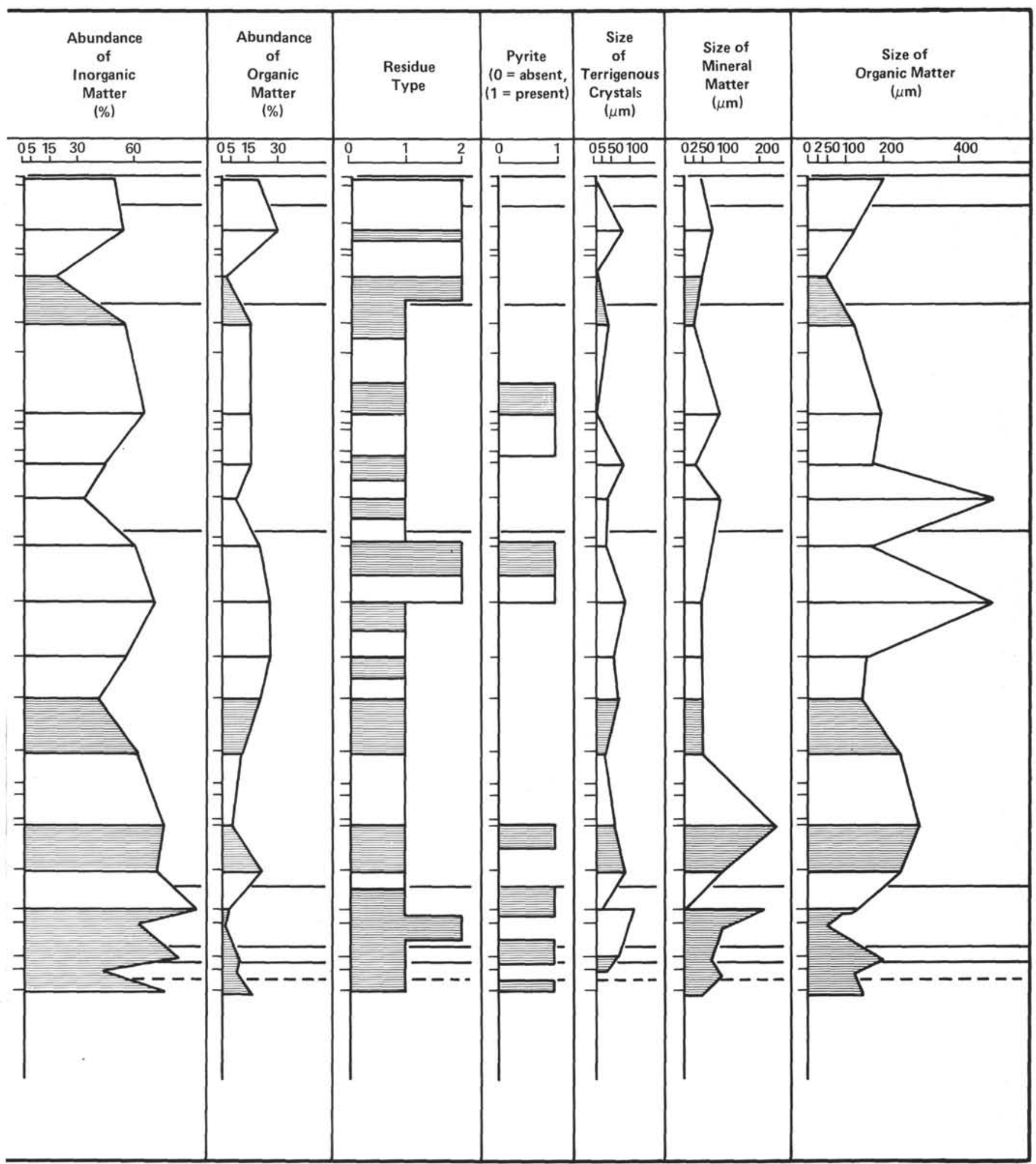

Figure 1. (Continued).

residue is black, but further down it is brown to the bottom of the hole, where it again becomes black.

\section{COLOR OF ALCOHOL-GLYCERIN SOLUTION}

The residues were preserved in vials with ethyl alcohol and glycerin to prevent the residues from becoming hard and to facilitate the making of slides.
After a few days, this solution can become colored, possibly because organic substances have been dissolved. These colors are classified in 8 basic groups: colorless and white; yellow; greenish yellow; light yellow; orange yellow; orange; dark orange; reddish orange and red.

The color chart for each hole (see Figs. 1-3) is based on the color of the solvent containing the residue ob- 


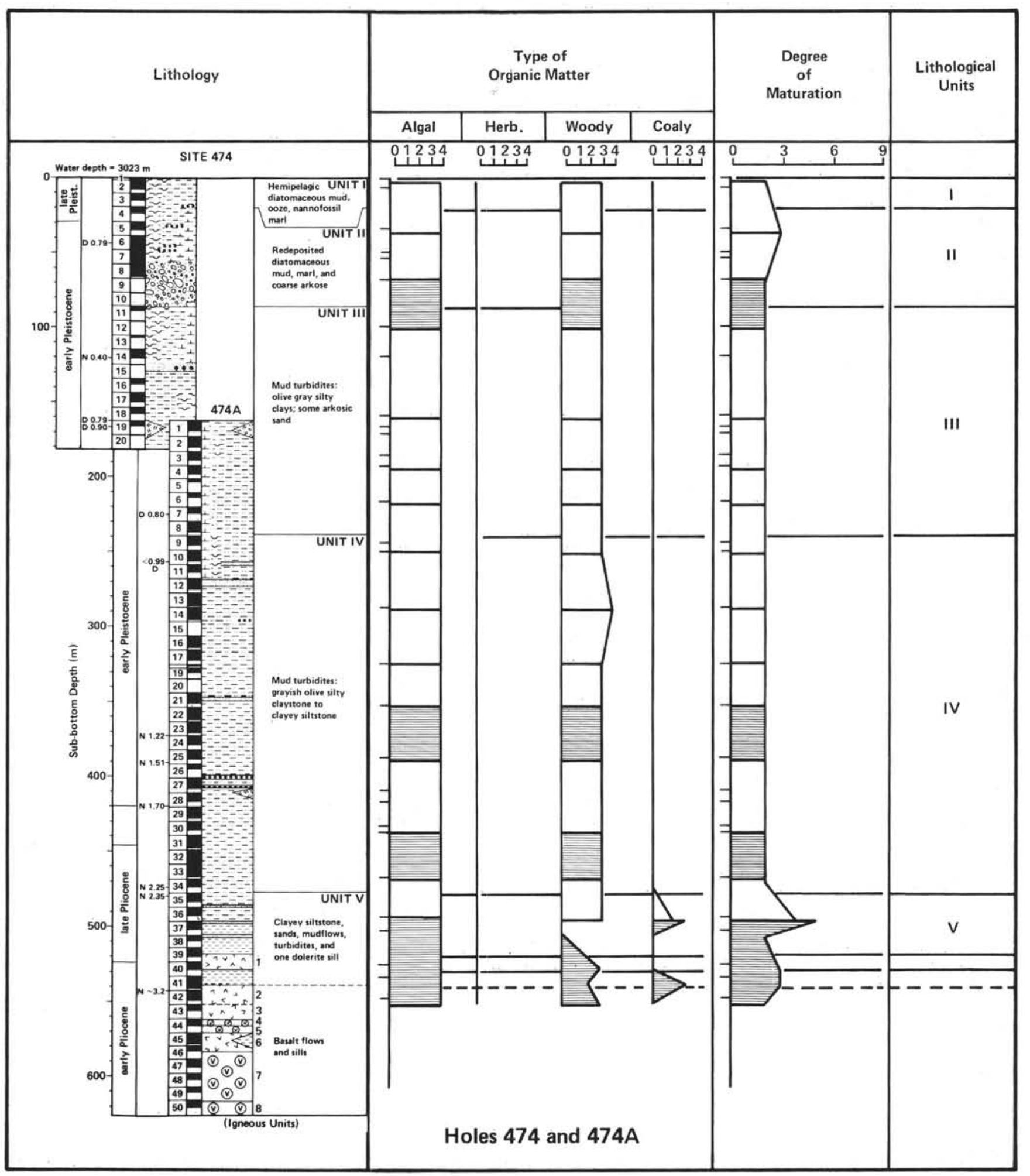

Figure 1. (Continued). 
tained by the kerogen technique. These colors are in general weaker than those of the usual palynological residue, possibly because of the chemical action of nitric acid and potassium chlorate on the organic matter.

\section{Mouth of the Gulf (Fig. 6)}

In residue preparations from Holes 474-475 the solvent is colorless and white from top to bottom. In samples from Cores 476-15 (135.67 m), 476-18 (166.15 m), and 476-21 (198.50 m) (Units II, III, and IV), the solvent is highly colored. In this same hole, Units IV and $\mathrm{V}$, the maturation index increases rapidly as the solvent color diminishes. The maximum coloration in Core 47621 is related to glauconite sands with phosphorite and pyrite just above a laminated sapropelic claystone with a petroliferous odor.

\section{Guaymas Basin (Fig. 6)}

In Holes $477-478$, there is a different relationship between the color of the solvent and that of the residue. The highest color values are generally located in Unit I from Holes 477 and 477A, increasing from the top to the upper part of the sill. Solvent color values are lowest in Unit II.

In Hole 478, Unit I, the solvent color varies by from 1-2 color values. The highest values are found in Unit II, near the base of the dolerite sills and at the base of the sedimentary sequence above the dolerite intrusion at the bottom of the hole.

\section{ABUNDANCE OF INORGANIC MATTER}

Inorganic matter refers to the mineral residue that is insoluble in hydrochloric and hydrofluoric acids. It is composed of terrigenous minerals, crystalline debris, and amorphous mineral matter in the sediments, plus minerals formed by acids acting on the different components of the sediment.

The plotted values were obtained from optical analysis of the residue using contrast-phase illumination and a $16 \times$ magnification objective. These values are relative; they correspond to the optical estimate of the different abundances of residue components.

In Figures 1-3, vertical variation in the abundance of mineral matter is correlated with other characteristics of the residue in each hole.

\section{Mouth of the Gulf (Fig. 7)}

In all holes here there seems to be a direct correlation between lithology and the abundance of mineral matter in the palynological residue.

Holes 474 and $474 A$. The maximum values occur in Units I, II, and IV, in particular in diatomaceous muds, silty claystone, and clayey siltstone. The minimum value occurs in Core 474A-8 (65.71 m), which is composed of coarse arkose.

Hole 475. The highest values occur in Unit I, in hemipelagic diatomaceous muds. From Unit III toward the bottom of the hole, mineral content decreases.

Hole 476. The maximum abundance occurs in hemipelagic mud at the top of Unit I and at the base of Unit
II; from Unit III to Unit V, mineral content in the residue rapidly decreases.

\section{Guaymas Basin (Fig. 7)}

Holes 477 and $477 \mathrm{~A}$. The maximum values of mineral matter are found in Unit I, above the dolerite sill, in olive brown diatomaceous ooze. Other maxima occur in Cores 477-16 $(118.74 \mathrm{~m})$ and 477-23 $(191.00 \mathrm{~m})$ beneath the sill and in Core 477A-6 (209.90 m) near the bottom of the hole, in hydrothermal sediments with epidote.

Hole 478. The maximum mineral content occurs in muddy diatomaceous ooze above the sills. Unit II beneath the sills contains the lowest quantity of mineral matter of all the samples.

\section{ABUNDANCE OF ORGANIC MATTER}

The organic matter present in the palynological residue has both continental and marine origins. Generally the two vary in an almost parallel fashion (see Figs. $1-3)$, but in some samples they diverge. Since both types of organic matter are present in the residue, it is necessary to relate abundance to predominant type in order to determine its origin.

\section{Mouth of the Gulf (Fig. 8)}

In Holes 474-476, the abundance of organic matter increases as we move from the continental toward the open marine environment. The average content increases from Hole 475 to Hole 476 and finally to Holes 474 and $474 \mathrm{~A}$. In all these sites the predominant organic matter is algal-sapropelic. The maximum abundance of organic matter occurs in Core 475-17 (150.25 m), the minimum in Core 474-8 $(65.71 \mathrm{~m})$, in coarse arkose.

\section{Guaymas Basin (Fig. 8)}

Hole 477. The plots of mineral and organic matter vary in a nearly parallel fashion, except that where mineral values are very high the organic content decreases. In Unit I, above the dolerite sill, the organic matter is abundant and predominantly algal-sapropelic; in Unit II, beneath the sill, it is composed of woody and coaly material and is abundant only at the bottom of the hole.

Hole 478. Unit I contains a very low quantity of organic matter, but in Unit II the quantity increases from the sills toward the bottom. The predominant organic matter is algal-sapropelic and woody in almost equal quantities.

\section{TYPE OF PALYNOLOGICAL RESIDUE}

The type of palynological residue is determined by the interrelation among its components and can be classified under two headings- "regular" and "irregular." "Regular" refers to homogeneous grain size, shape, and coloration of the predominant components of the residue. "Irregular" refers to components with different sizes, shapes, and coloration. In general, these characteristics are very important in interpreting sedimentary conditions, because homogeneity is directly related to a quiet, very low energy environment, lack of homogeneity to high-energy sedimentary environments. 


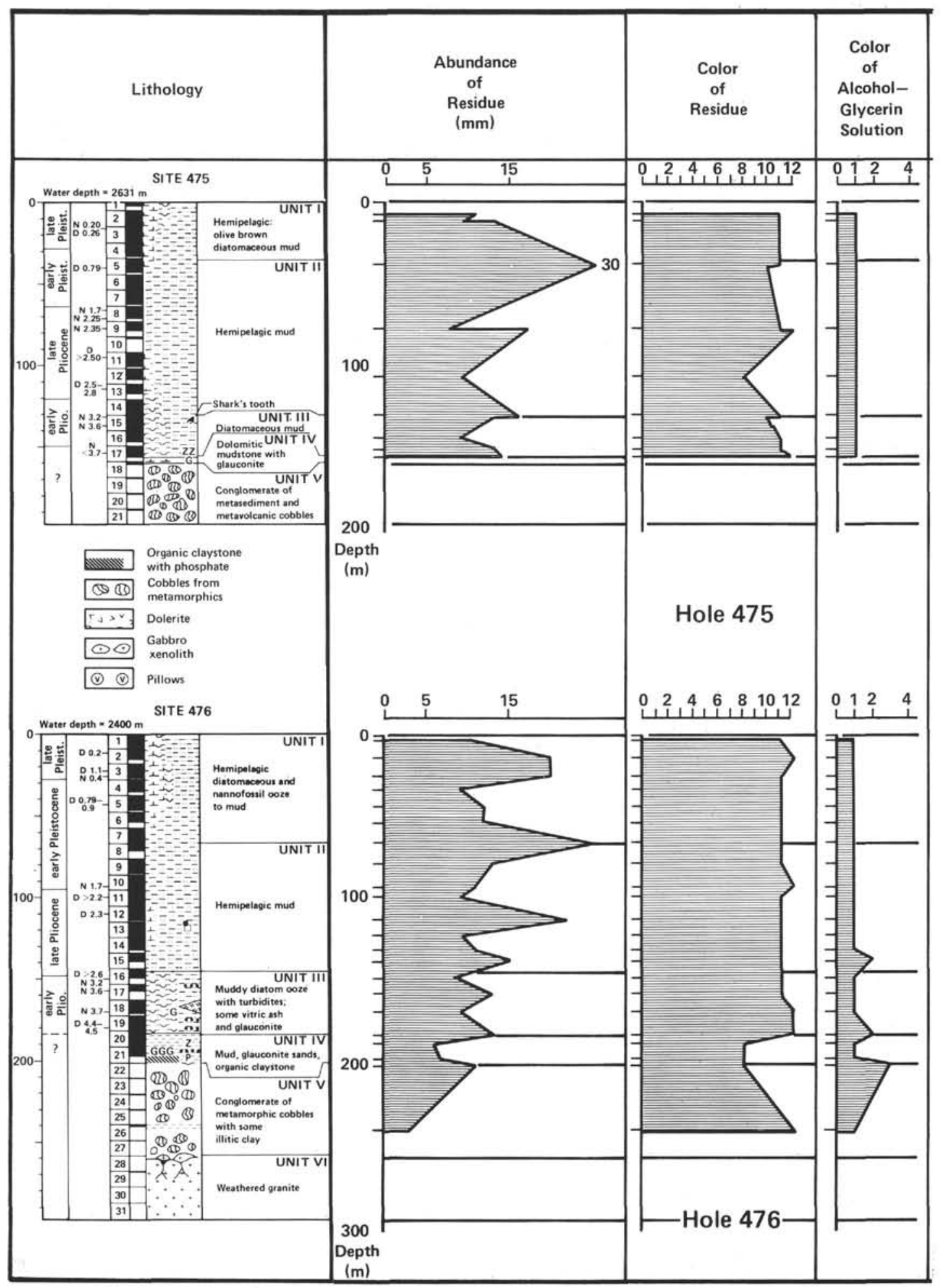

Figure 2. Vertical variation in selected characteristics of the palynological residue, Holes 475 and 476 . (For explanations, see Fig. 1.)

Figures $1-3$ relate the vertical variation in the residue type for each hole with the other characteristics.

\section{Mouth of the Gulf (Fig. 9)}

Sediments here are clearly differentiated, as reflected by the nature of the palynological residue in samples from Holes 474-476.
Holes 474 and $474 A$. Regular types predominate in Units I (Core 474-1, 0.42 m) and II (Core 474-5, 35.45 $\mathrm{m})$, composed of hemipelagic diatomaceous muds, oozes, and nannofossil marls as well as redeposited diatomaceous mud and mud turbidites. At the boundary between Units III and IV (Core 474A-9, $245.13 \mathrm{~m}$ ) and in Core 474A-37 (496.08 m) from Unit V we also found 


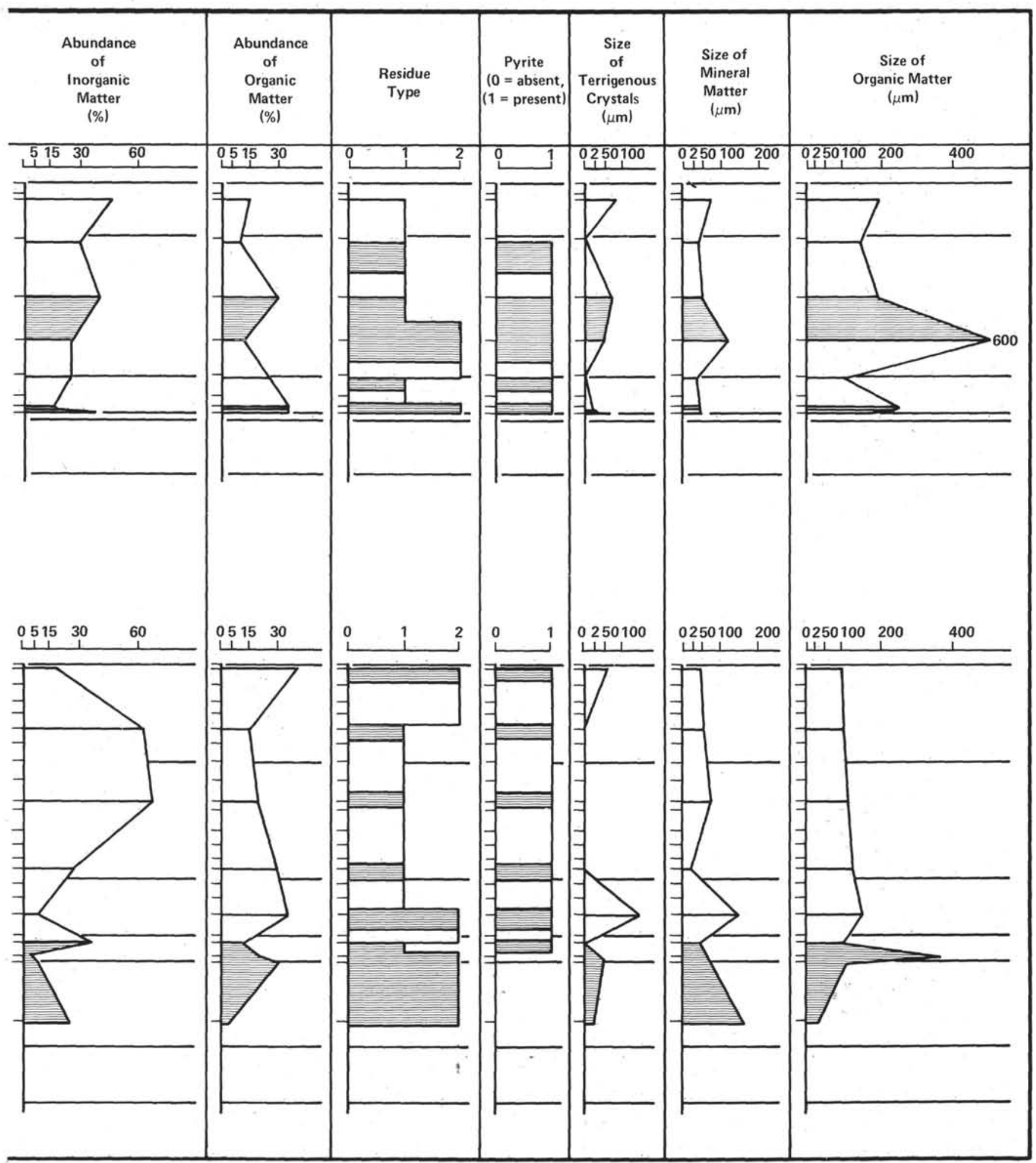

Figure 2. (Continued).

regular residue. This lithology indicates a very low energy sedimentary environment. In Units III and IV and the highest part of Unit V, composed of mud turbidites with arkosic sands and clayey siltstone, sand, mudflows, and turbidites, the residue is irregular, indicating a higher-energy sedimentary environment.
Hole 475. The residue in Unit I and the upper part of Unit II is irregular, although the lithologic units consist of hemipelagic muds. Toward the bottom of the hole, the residue becomes regular in Cores 475-12 (106.64 m) and $475-17(150.25 \mathrm{~m})$, composed of fine sediments with diatomaceous muds. 


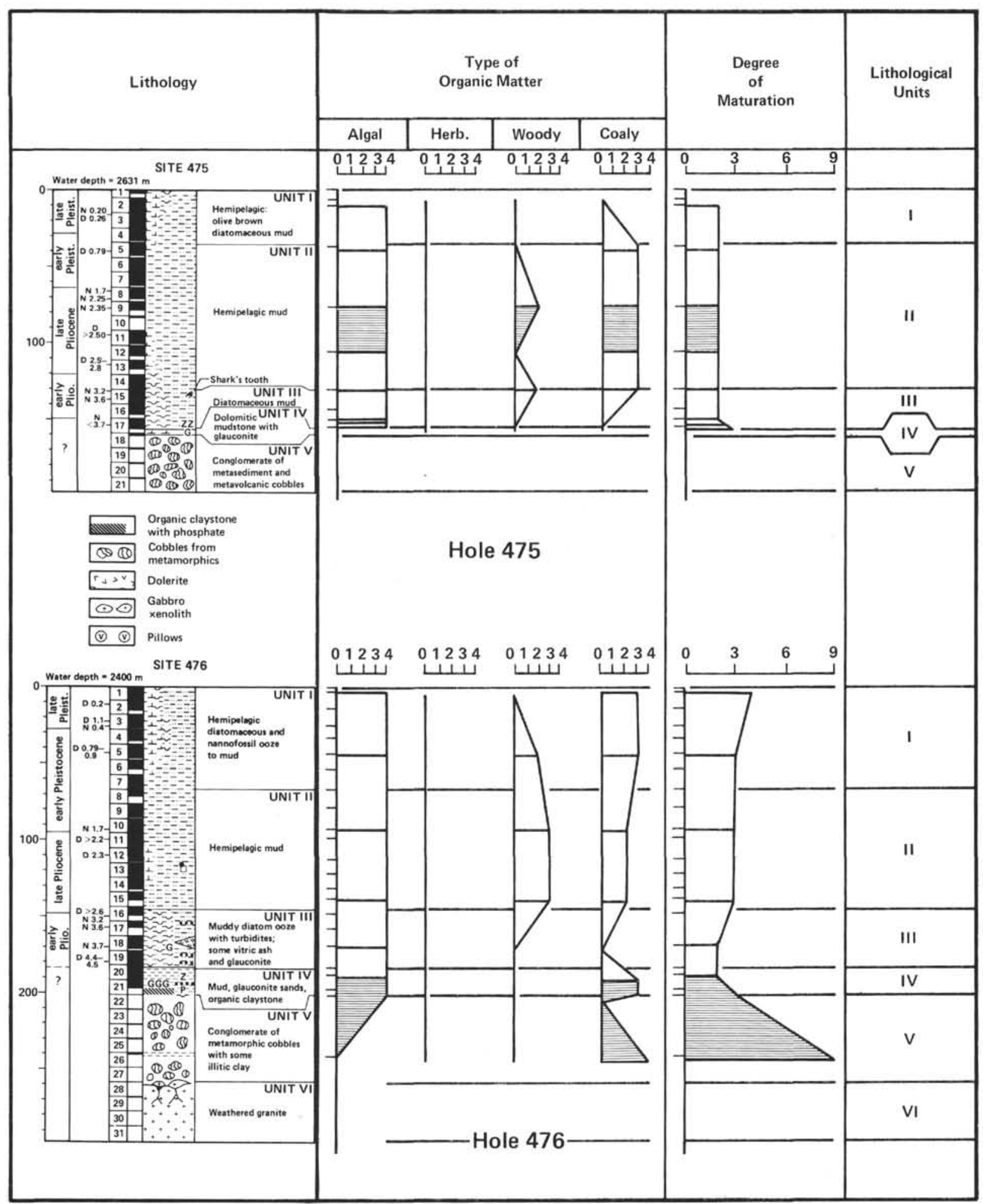

Figure 2. (Continued).

Hole 476. Higher-energy conditions occur in Unit II, where the residue is predominantly irregular. Regular residue predominates at the top of Unit I, and in Units III, IV, and V in samples composed of hemipelagic diatomaceous oozes and muds, glauconitic sands, and organic claystone and mud. Regular residue is also present in Core 476-26 (237.97 m) in gray sandy clay strata in a conglomerate composed of metamorphic cobbles and an illitic clay unit.

\section{Guaymas Basin (Fig. 9)}

Here the residue was predominantly irregular, except for some regular samples taken from diatomaceous ooze and mudstones. 
Holes 477 and $477 A$. Residue from samples with algal organic matter at the top of Unit I, Cores 477-2 (5.77 $\mathrm{m})$ and 477-3 (10.57 m), is regular. From Cores 477-4-7 it is irregular. Residues from Unit II, beneath the dolerite sill, are irregular from the top to Core 477A-8 $(229.16 \mathrm{~m})$. At the bottom of this hole there is an interval of regular residue in brecciated sediments with silty, sandy, and clay patches. Irregular residue is generally related to the presence of woody and coaly organic matter in the sediment.

Hole 478. Regular residue is present in Unit $\mathrm{I}$, Cores $478-1(0.35 \mathrm{~m})$ and $478-6(47.56 \mathrm{~m})$ in olive brown muddy diatomaceous oozes. In Unit II, beneath the dolerite sills in diatomaceous mudstone, the residue again becomes regular in Cores 478-32 (273.66 m), 478-36 $(311.56 \mathrm{~m}), 478-39(329.70 \mathrm{~m})$, and $478-40(338.08 \mathrm{~m})$.

\section{PYRITE IN THE PALYNOLOGICAL RESIDUE}

Pyrite is present only in the palynological slides containing a kerogen residue. This crystalline and spheroidal mineral is correlated more with the presence of woody organic matter and continental palynomorphs than with marine organic matter, and is more abundant in Guaymas Basin sites than in those at the mouth of the Gulf (see Figs. 1-3).

\section{Mouth of the Gulf (Fig. 10)}

Holes 474 and $474 \mathrm{~A}$. Pyrite is rare, and is present only in Units III, IV, and V, in mud turbidites near sandy intervals. In Unit III, it was found only in Core 474-18 $(156.74 \mathrm{~m})$; in Unit IV, in Cores 474A-9 $(245.13 \mathrm{~m})$ and 474A-30 (431.18 m); in Unit V, in Cores 474A-35 (460.58 $\mathrm{m}), 474 \mathrm{~A}-36$ ( $486.77 \mathrm{~m}, 486.83 \mathrm{~m})$ 474A-39 (518.65 m), and $474 \mathrm{~A}-41(541.21 \mathrm{~m})$.

Hole 475. Pyrite was found only in samples of hemipelagic and diatomaceous muddy sediments from Units II and III, in Cores 475-5 (39.54 m), 475-9 (77.95 $\mathrm{m}), 475-12(106.64 \mathrm{~m}), 475-15(130.34 \mathrm{~m})$ and $475-17$ $(150.25 \mathrm{~m})$.

Hole 476. Pyrite is present in hemipelagic sediments and claystone with plant debris from Units I, II, and III, Cores 476-1 (2.54 m), 476-5 (42.56 m), 476-10 (90.91 $\mathrm{m}), 476-15(135.67 \mathrm{~m}), 476-18(166.15 \mathrm{~m})$, and $476-20$ $(185.15 \mathrm{~m})$.

\section{Guaymas Basin (Fig. 10)}

Holes 477 and $477 A$. Pyrite is present in all residues. In Unit I it is related to woody organic matter. In the upper part of Unit II woody material is very abundant, but it decreases downhole. Coaly material-largely of woody origin-increases in abundance from top to bottom of this unit and may be derived downward from thermal alteration of woody matter, which reaches a maximum at the bottom of the hole where temperature maxima related to hydrothermal alteration of sediments occur. This could largely explain the presence of pyrite in Unit II and could be the origin of the $\mathrm{H}_{2} \mathrm{~S}$ detected in this unit.

Hole 478. Pyrite is present in all analyzed samples from Units I and II, in which the organic matter is algal, woody, and coaly. Woody and coaly organic matter is abundant in Unit I, from Core 478-6 (47.56 m) to Core 478-17 (149.86 m), a section of turbidite sediments with irregular palynological residues related to higher-energy sedimentary conditions.

\section{SIZE OF TERRIGENOUS CRYSTALS AND CRYSTALLINE DEBRIS}

Crystals and crystalline debris from terrigenous minerals - generally found in the palynological residue from turbidites and coarse sediments-are related to highly stable minerals such as zircon, tourmaline, ilmenite, rutile, and the like. Their maximum transport distance is controlled by the energy of the sedimentary environment and also by the grain size of the particles. (See Figs. 1-3.)

\section{Mouth of the Gulf (Fig. 11)}

Holes 474 and $474 \mathrm{~A}$. Crystals and crystalline debris reached maximum size in Units II-V. In Unit II, Core 474-5 $(35.45 \mathrm{~m})$, crystals between 50 and $100 \mu \mathrm{m}$ were found in sediments with coarse arkose. In Hole 474A, maximum sizes occurred in Unit III (Core 474A-3, $189.75 \mathrm{~m}$ ), Unit IV (Cores 474A-13, $282.85 \mathrm{~m}$; 474A-21, $347.95 \mathrm{~m}$; and $474 \mathrm{~A}-33,460.58 \mathrm{~m}$ ), and in Unit V (Cores 474A-37, 496.08 m; 474A-39, $518.65 \mathrm{~m}$ ). These high values are related to turbidites with sandy intervals deposited under high-energy conditions.

Hole 475. Two maxima in the size of terrigenous crystals and crystalline debris occur in Units I and II, in Core 475-2 $(11.51 \mathrm{~m})$ and Core $475-9(77.95 \mathrm{~m})$. Both units consist generally of hemipelagic mud, but Core 475-2 has some sandy layers and Core $475-9$ is silty clay with glauconitic sand. In Unit III, Core 475-17 (150.25 $\mathrm{m})$ at the bottom of the diatomaceous mud, crystals and crystalline debris are $>50 \mu \mathrm{m}$.

Hole 476. Maxima occur in Units I, III, and IV. Unit I, Core 476-1 $(2.54 \mathrm{~m})$, composed of hemipelagic diatomaceous and nannofossil mud, contained crystals and crystalline debris $>50 \mu \mathrm{m}$. Unit III, Core 476-18 (166.15 m) contained crystalline debris and crystals $>150 \mu \mathrm{m}$; sediment here consisted of vitric ash (rhyolitic) in muddy diatomaceous ooze. In Unit IV, particles $>50 \mu \mathrm{m}$ occurred in Core 476-21 (194.11 m), consisting of glauconitic sands with phosphorite and pyrite above a sapropelic claystone. The size decreased downhole; in Core 26 $(237.97 \mathrm{~m})$ particles were only $25 \mu \mathrm{m}$ in sandy clay, above weathered granite.

\section{Guaymas Basin (Fig. 11)}

The distribution of terrigenous crystals and crystalline debris in Holes 477-478 occurs uniformly only in residues from Unit I of the sedimentary sequences.

Holes 477 and $477 A$. The distribution of this kind of crystalline material seems to be related to abundant mineral matter in the residue. The largest particles occur in Cores 477-3 $(12.63 \mathrm{~m})$ and 477-5 $(25.17 \mathrm{~m})$ in turbidite sequences with basal sands from Unit I. Crystalline material is not continuously present in Unit II. In Cores 477-15 (106.15 m), 477-16 (118.74 m), 477-20 $(172.40 \mathrm{~m})$, and $477 \mathrm{~A}-7(210.61 \mathrm{~m})$, particles are $\geq 50$ $\mu \mathrm{m}$. 


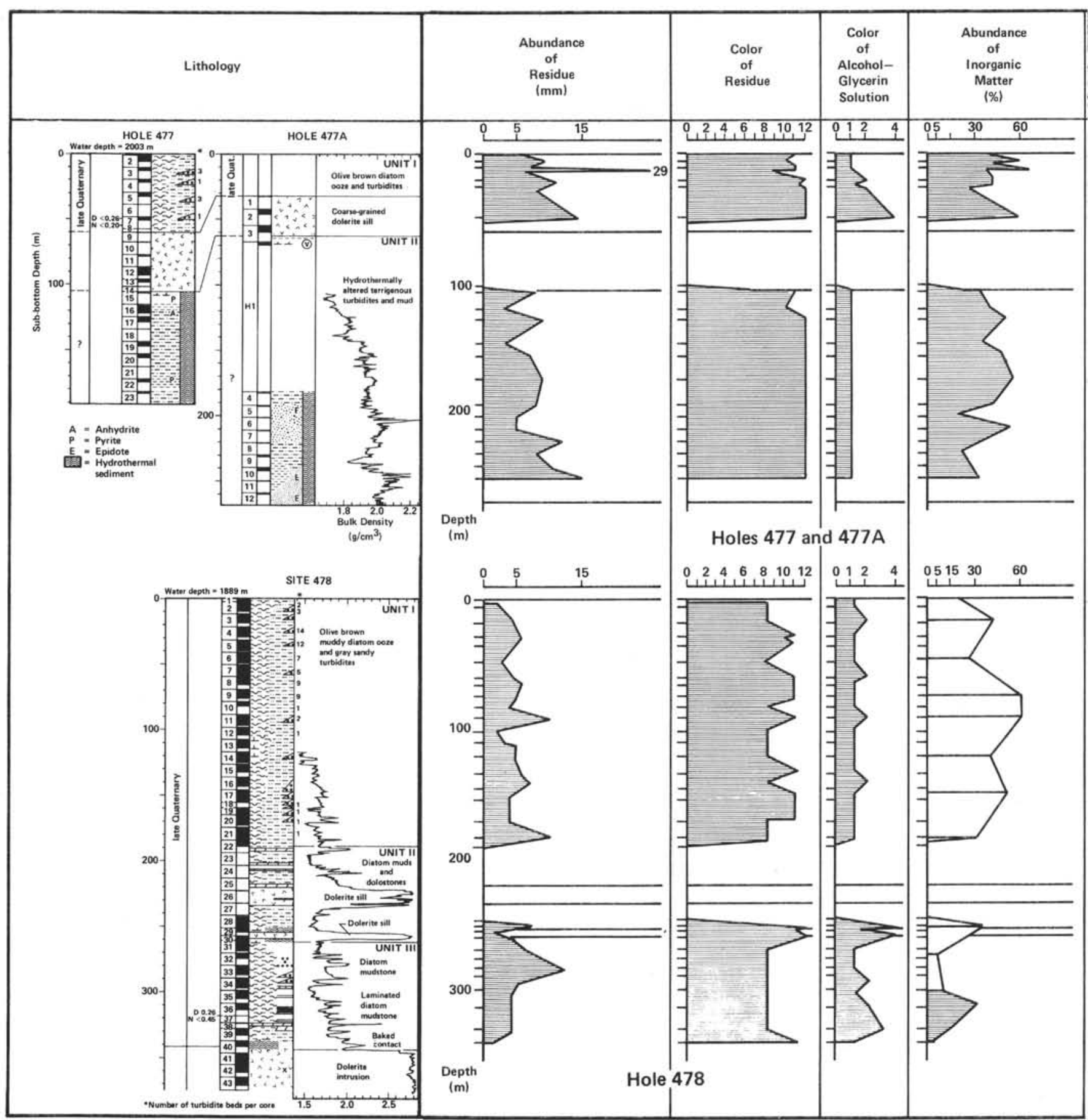

Figure 3. Vertical variation in selected characteristics of the palynological residue, Holes 477-478. (For explanations, see Fig. 1.)

Hole 478. Distribution of crystalline material is similar to Holes 477 and 477A. Terrigenous particles $>50$ $\mu \mathrm{m}$ are present throughout turbidite sequences in the upper part of Unit I. These sediments occur from Cores 478-1 $(0.35 \mathrm{~m})$ to $478-17(149.86 \mathrm{~m})$. From Core 478-17 to the bottom of Unit I $(220.0 \mathrm{~m})$ no continental crystalline debris occurs, but it does appear again in Cores 478-29 (251.43 m), 478-35 (301.60 m), 478-36 (311.56 $\mathrm{m})$, and $478-40(338.07 \mathrm{~m})$ of Unit II, in sizes increasing from 25 to $50 \mu \mathrm{m}$.

\section{SIZE OF MINERAL MATTER, EXCLUDING CRYSTALS AND CRYSTALLINE TERRIGENOUS REMAINS}

This mineral matter includes particles without a crystalline habit and comes generally from amorphous matter in sediments and from minerals newly formed during the action of acids upon the different components of the sediment. This matter is composed of granules and aggregates of chemical origin; it is possibly ralstonite, a 


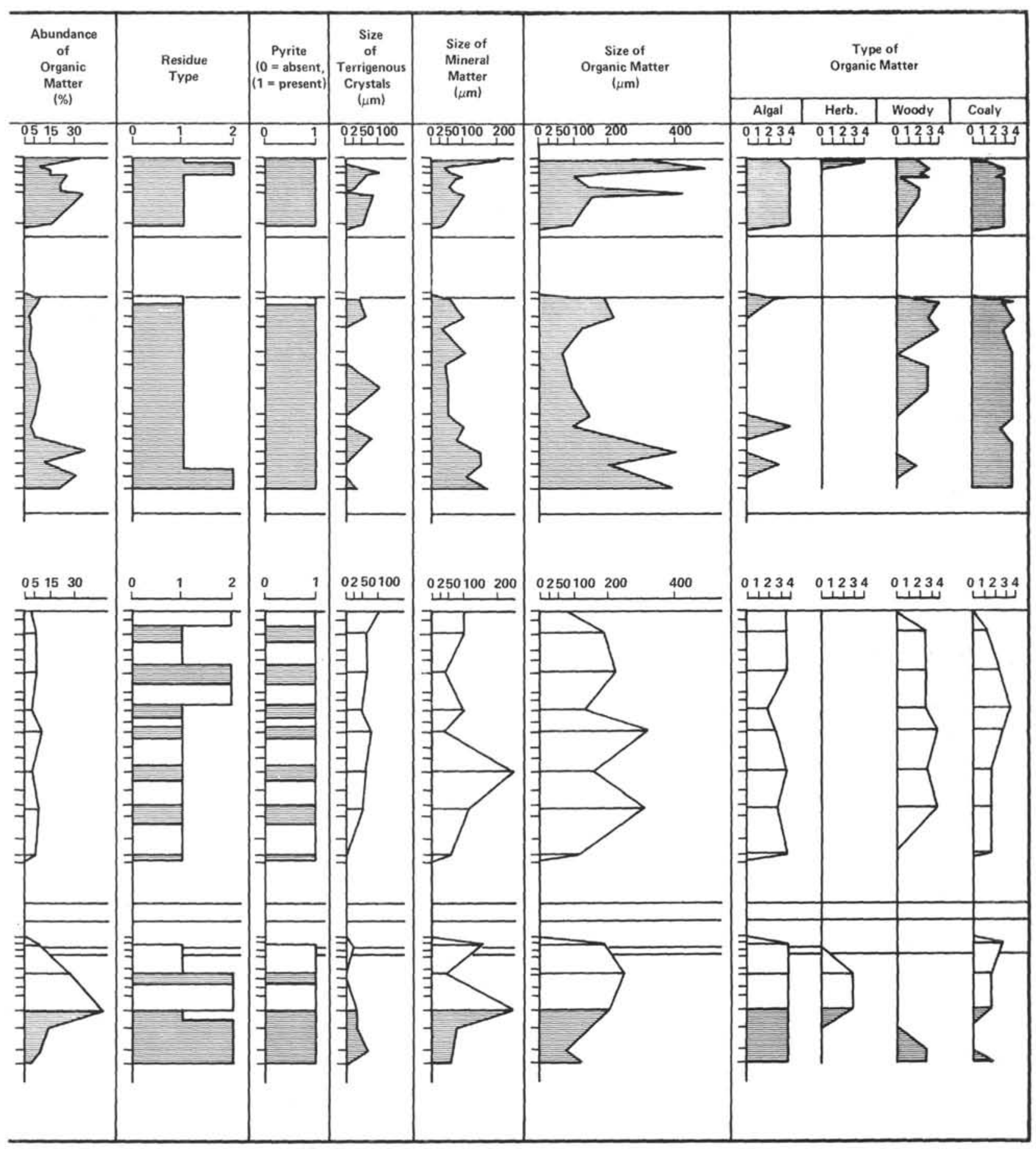

Figure 3. (Continued).

colorless, white, or yellowish mineral $\left[\mathrm{Na}_{\mathrm{x}} \mathrm{Mg}_{\mathrm{x}} \mathrm{Al}_{2 \mathrm{x}}(\mathrm{F}\right.$, $\mathrm{OH})_{6} \cdot \mathrm{H}_{2} \mathrm{O}$ ] with octahedral crystals which are completely translucent and hardly visible in normal light. Description, quantification, and measurement are possible only under phase-contrast conditions. In phasecontrast optical analysis this material appears white and is possibly derived from carbonate sediments. The vertical variation in the size of the particles for each site is shown in Figures 1-3.

\section{Mouth of the Gulf (Fig. 12)}

Particularly in Holes 475 and 476, mineral matter size generally increases as the grain size of crystals and crystalline debris of terrigenous origin increases. In Holes 474 and $474 \mathrm{~A}$ some differences appear.

Holes 474 and $474 A$. Units III and IV display some high values which do not correspond to those of the crystals and crystalline debris. In Unit III there are 2 


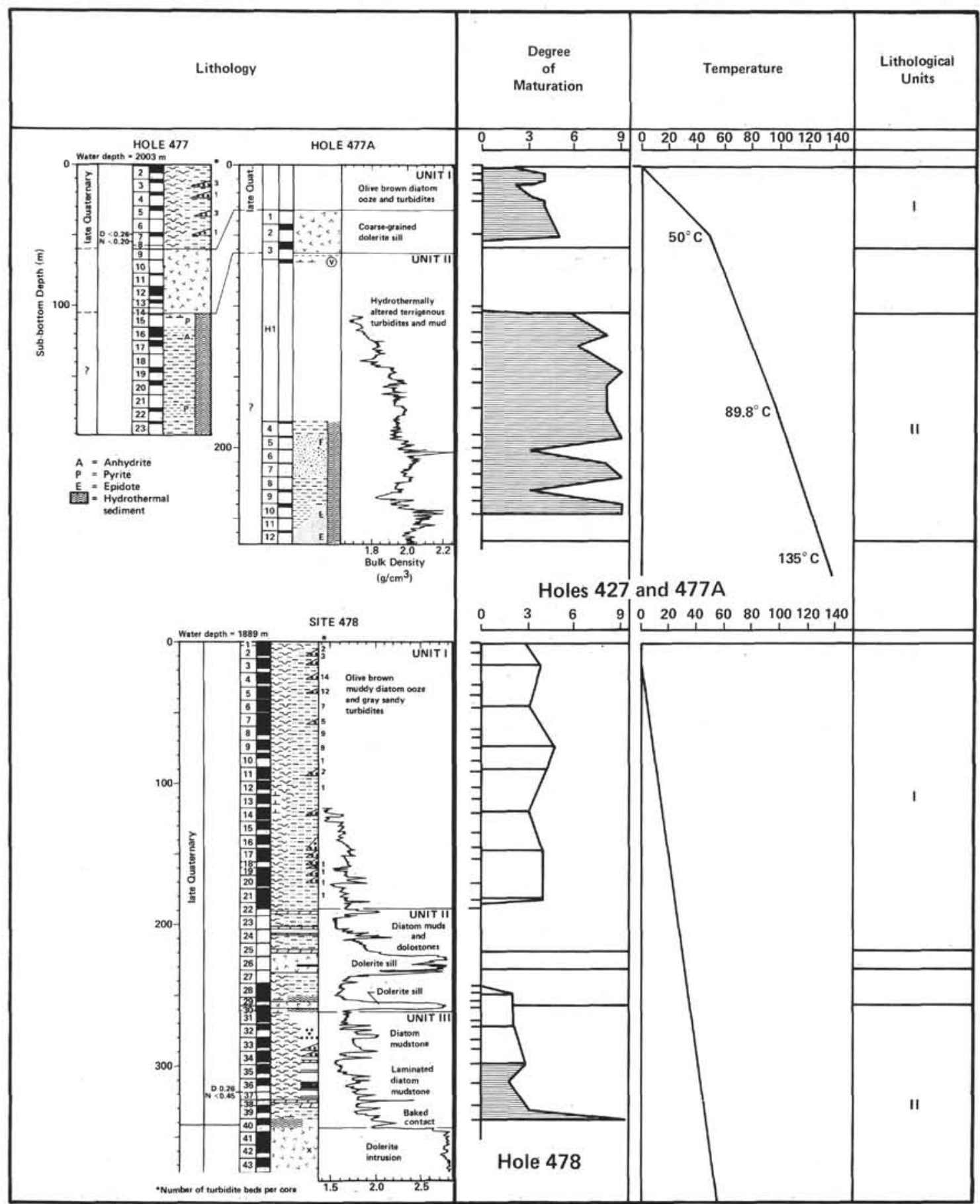

Figure 3. (Continued).

maxima in Cores 474-18 (165.74 $\mathrm{m})$ and 474A-6 (213.36 $\mathrm{m})$, in slightly calcareous sediments. In Unit IV, in Core $474 \mathrm{~A}-30(431.18 \mathrm{~m})$ there are fragments of shallowwater carbonates. In Unit V high values are reached in Core 474A-36 (486.83 m) in sediments composed of silty claystone to clayey siltstone. This relationship between large amounts of mineral matter and carbonate sediments demonstrates that the residue still contains carbonate particles not completely dissolved by hydrochloric and hydrofluoric acids. This mineral matter could also be derived from the chemical action of acids on carbonates.
Holes 475 and 476. Both curves, one corresponding to the size of crystals and crystalline debris and the other to the size of mineral matter, have almost the same vertical variation, indicating that both types of material are terrigenous.

\section{Guaymas Basin (Fig. 12)}

At all sites there is a good correlation between size of mineral matter and the size of crystals and crystalline debris in the upper part of Unit I. In Unit II, there is no correlation. 


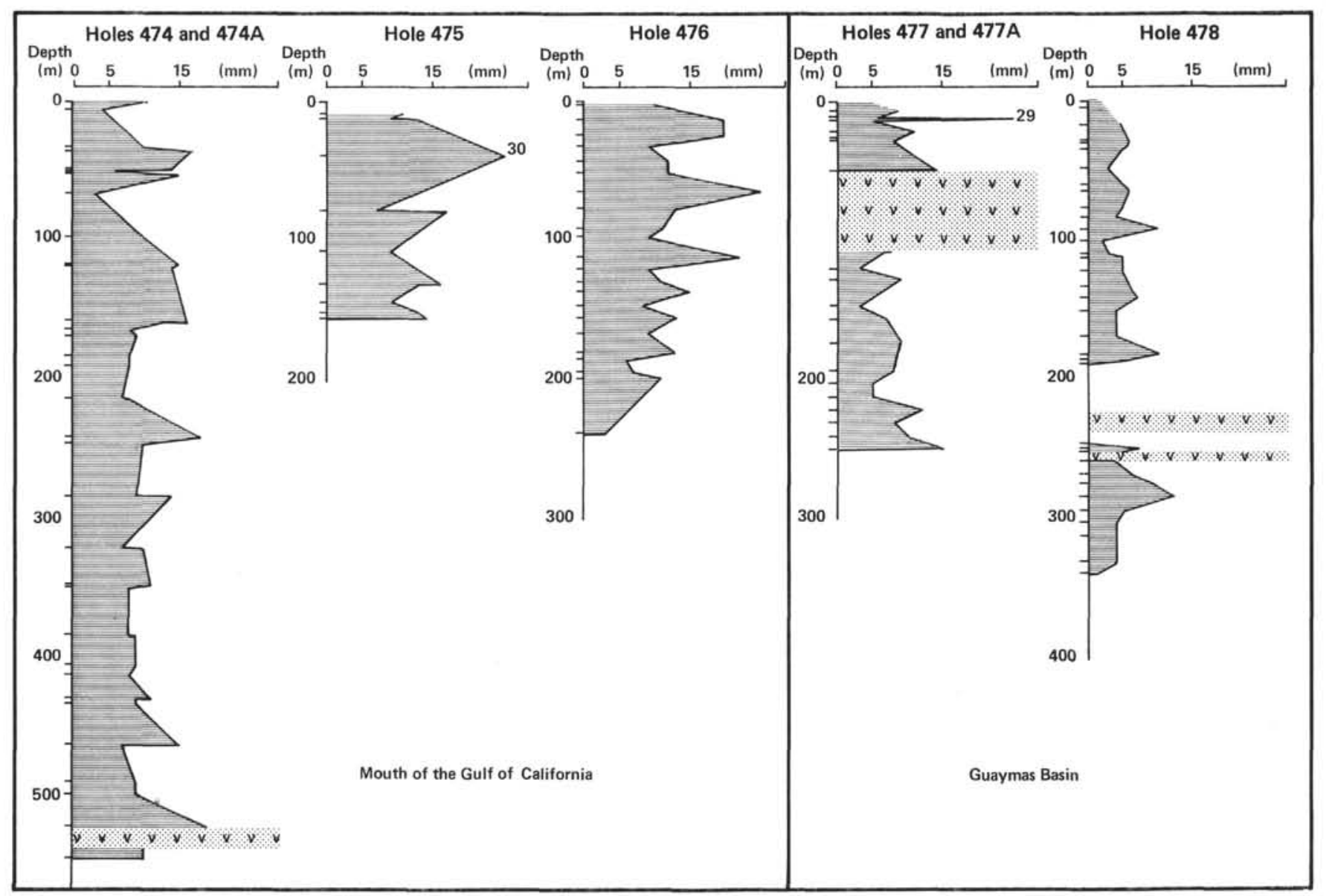

Figure 4. Abundance of the palynological residue, Holes 474-478.

Holes 477 and $477 A$. In Unit I, mineral matter of terrigenous origin was directly correlated with the crystalline matter. In the upper part of Unit II, there are mineral matter values higher than $50 \mu \mathrm{m}$ (Cores $477-16$, $118.74 \mathrm{~m} ; 477-19,154.42 \mathrm{~m})$. Toward the bottom of the unit this mineral matter decreases in size until 200 meters depth is reached; it then increases to a maximum value of $200 \mu \mathrm{m}$. Unit II consists of embedded dolomite associated in its upper part with anhydrite. In the lower part of this unit the mineral matter may be derived from the chemical alteration of dolomite and minerals from the epidote group-zoisite and feldspar-which are the most abundant minerals.

Hole 478. The upper part of Unit I' contains a higher proportion of chemical than of detrital mineral matter, related to the presence of calcareous nannoplankton. The maximum size of mineral matter $(>200 \mu \mathrm{m})$ occurs in Core 478-14 $(121.08 \mathrm{~m})$, in unspecified carbonates and thin, dolomitic clay layers. The mineral matter attains sizes $>100 \mu \mathrm{m}$ in Core 478-29 $(251.43 \mathrm{~m}), 1.7 \mathrm{me}-$ ters above the basalt (dolerite) sill, in sediments composed of black diatomaceous mud to silty clay. Immediately below the sample, the sediment becomes a black, silty, indurated claystone with dolomite $( \pm 30 \%)$, just above the sill. In Unit II, beneath the dolerite sill, in Core 478-35 (301.60 m), mineral matter of chemical origin reaches $>200 \mu \mathrm{m}$ in dolomite and in calcareous cement.

\section{SIZE OF THE ORGANIC MATTER}

Interpreting the size of the organic matter in terms of sedimentary environment depends on previous knowledge of organic matter type. When organic particles are terrigenous (cuticles, woody fragments, pollen, spores, etc.) large sizes indicate a high-energy sedimentary environment near the coastline. In contrast, large particles of autochthonous organic matter (algal) generally indicate a lower-energy environment. In the mouth of the Gulf and in the Guaymas Basin, the correlation between size and type of organic matter and size of crystalline and other mineral matter is very interesting (see Figs. 1-3). At sites far from the coastline the maximum sizes occur in marine matter; at sites near the continent, maximum values are related to woody and coaly fragments.

\section{Mouth of the Gulf (Fig. 13)}

Holes 474 and $474 \mathrm{~A}$. Size of organic matter here displays two very high maxima ( $>500 \mu \mathrm{m}$ ) in Cores 474A-6 $(213.36 \mathrm{~m})$ and $474 \mathrm{~A}-13(282.85 \mathrm{~m})$. In Units I-III, except for Core 474-18 (165.74 m), large sizes correspond to marine organic matter. In Units IV and V the largest sizes of organic matter are related to continental woody debris. In Unit $\mathrm{V}$ we found both woody and coaly material, evidence that continental influence on sedimentary conditions is increasing from the top to the bottom of the stratigraphic column. In Core 474A-13, continental 


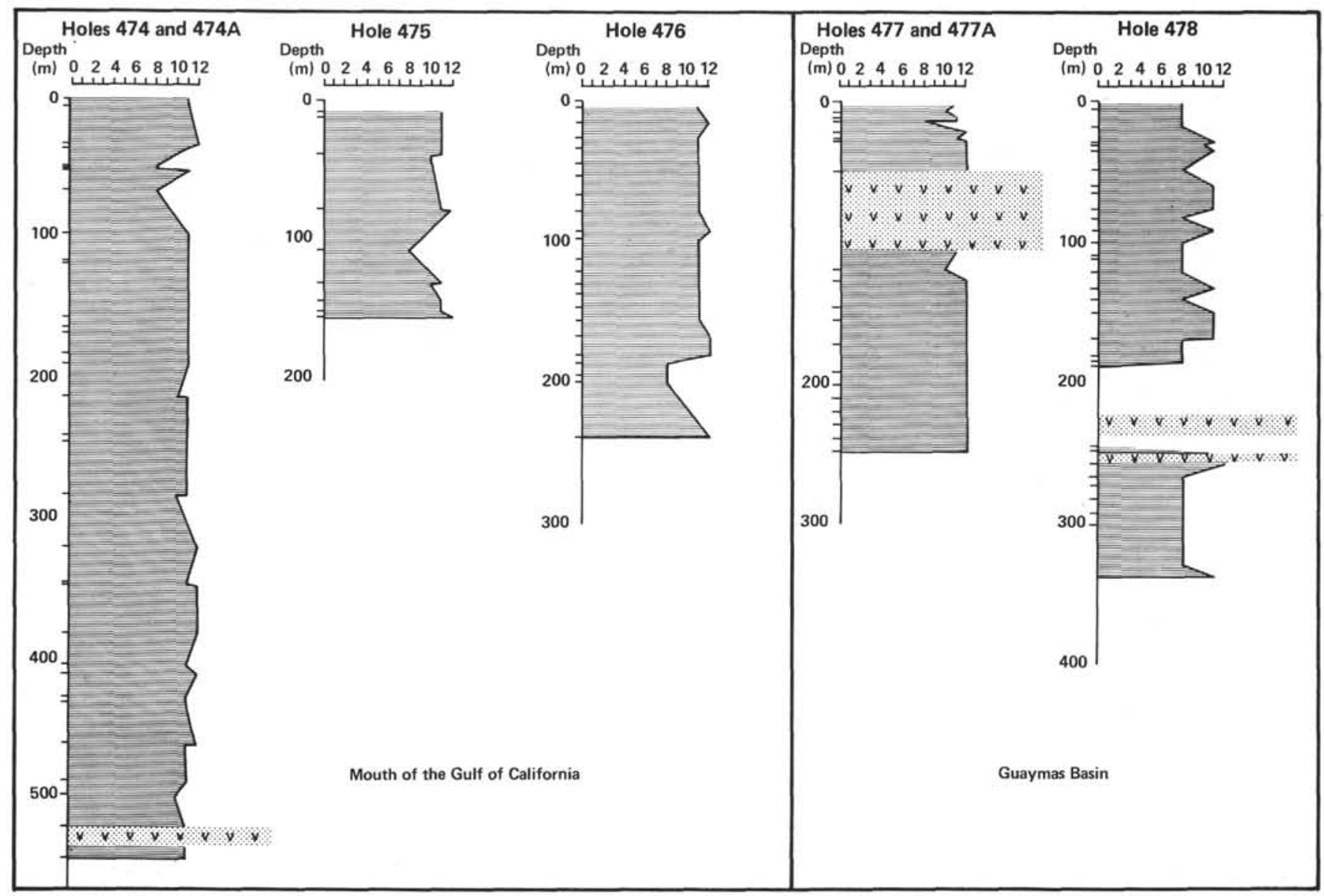

Figure 5. Color of the palynological residue, Holes 474-478. (For an explanation of the scale, see Fig. 1.)

organic matter reaches maximum sizes and woody matter reaches its maximum abundance. In Core 474A-37 $(496.08 \mathrm{~m})$, marine organic matter reaches minimum sizes in a layer of arkosic sandstone without woody material. There is no coaly material in Units I-IV.

Hole 475. Organic matter reaches maximum size in Unit II, which has a high content of woody and coaly material. In Unit I, Hole 475, the marine matter reaches $200 \mu \mathrm{m}$, indicating a marine environment; this matter is increasingly continental toward the bottom of Unit II. The maximum size of the organic matter $(600 \mu \mathrm{m})$ is reached in Core 475-12 (106.64 m) and corresponds to coaly fragments.

Hole 476. In Unit IV, Core 476-21 (194.11 m), woody fragments are infrequent, but coaly matter reaches 350 $\mu \mathrm{m}$. In Units I and II, organic matter is smaller in size $( \pm 100 \mu \mathrm{m})$ and is dominantly algal, indicating a gradually increasing marine environment toward the top.

\section{Guaymas Basin (Fig. 13)}

In Holes 477-478, maximum sizes of marine organic matter occur in the upper part of Unit I (Cores 477-2, $5.77 \mathrm{~m}$, and $477-5,25.17 \mathrm{~m}$; Cores $478-3-17,17.29-$ $149.86 \mathrm{~m}$ ). Size values in the lower part of Unit I in Hole 478 are related to woody material. In all these samples Unit II displays high size values for continental matter, but in Holes 477 and 477A hydrothermal influences have generated a clear difference in the organic matter composition in the sedimentary sequence. In these holes, the upper part of Unit II is composed of woody and coaly organic matter, without marine matter. Toward the bottom of the holes, the principal component is coaly material originating from thermal alteration of woody and marine material. Maximum values ( $>400 \mu \mathrm{m})$ in Unit II are reached at the bottom of the sedimentary column, in sandy material interrupted by a clayey layer.

Thus in Holes 477 and 477A the marine contribution occurs in Cores $477-2(5.77 \mathrm{~m})$ to $477-7(49.04 \mathrm{~m})$; the continental influence begins in Core 477-15 (105.52 m), and the marine contribution increases toward the bottom. In Hole 478, the sequence with a greater marine contribution includes Cores $478-1(0.35 \mathrm{~m})$ to $478-9$ $(75.67 \mathrm{~m})$. Woody, coaly, and herbaceous material of continental origin occur from Core 478 downhole.

\section{TYPES OF ORGANIC MATTER}

Organic matter was classified into four types, corresponding to three groups:

\begin{tabular}{ll}
\hline \multicolumn{1}{c}{ Groups } & \multicolumn{1}{c}{ Types } \\
\hline terrigenous & $\begin{array}{l}\text { herbaceous, woody } \\
\text { marine }\end{array}$ \\
mixture & $\begin{array}{l}\text { algal } \\
\text { coaly }\end{array}$ \\
\hline
\end{tabular}




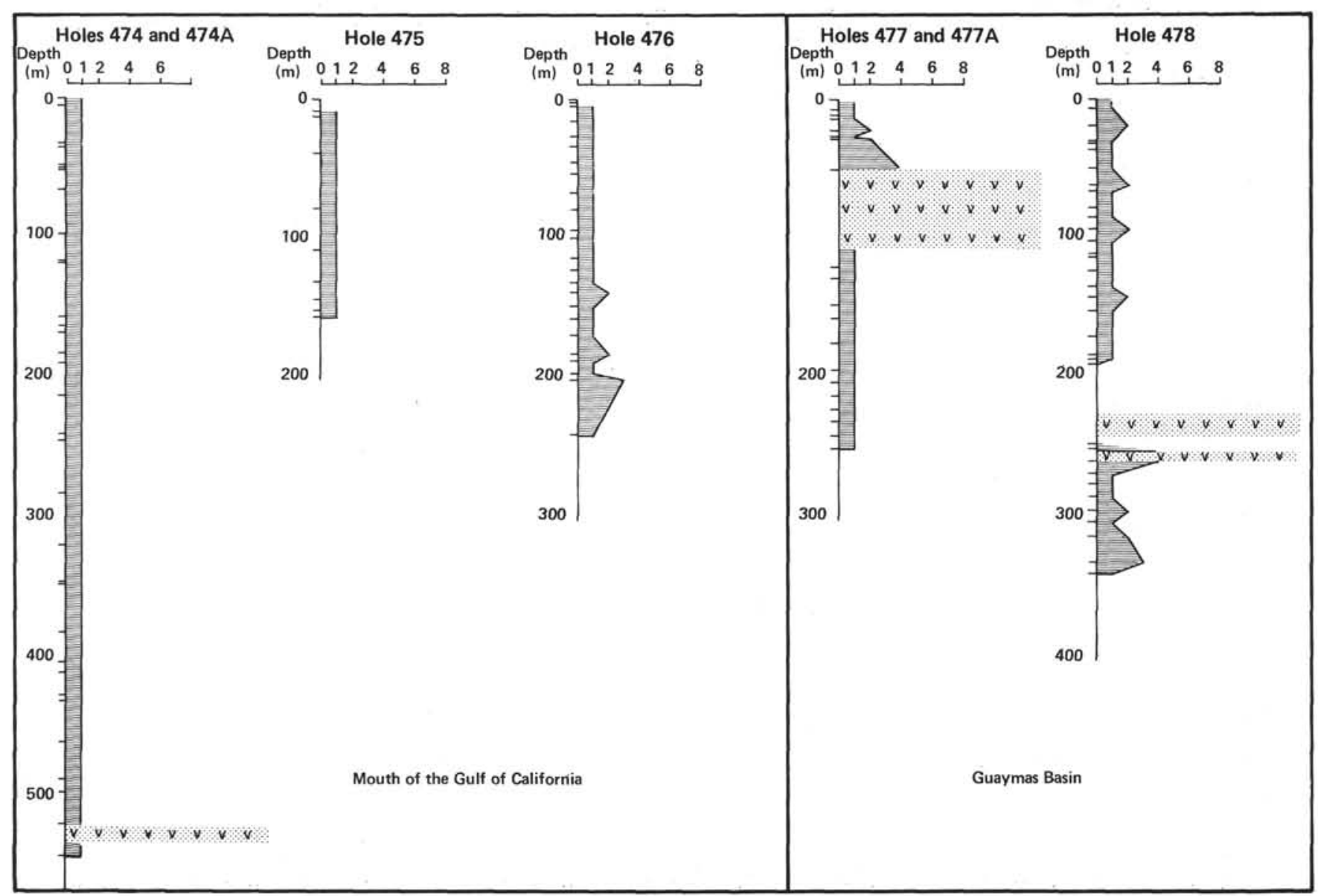

Figure 6. Color of the alcohol-glycerin solution. (For an explanation of the scale, see Fig. 1.)

Herbaceous and woody matter types are terrigenous. Coaly material may be terrigenous or marine. Algal matter, except for lacustrine sediment, is marine.

Herbaceous organic matter includes pollen, spores, and cuticle remains. Woody organic matter is composed of woody tissue fragments from vascular plants. Coaly material includes carbonaceous fragments from herbaceous, woody, and algal materials. Algal organic matter is composed of debris from uni- and multicellular algae. The predominance of one or another of these types of organic matter in the palynological residue allows us to define four principal types of palynofacies (Combaz, 1964) that are directly related to the sedimentary and diagenetic conditions that are the basis of different types of sediments and sedimentary rocks. Thus each sediment and sedimentary rock type corresponds to a palynofacies type. In general, the palynofacies are related directly to the organic content of the palynological residue. But since this residue includes mineral matter of different origins that is also related to sediment and sedimentary rock types and origins, it is convenient to consider palynofacies as corresponding not only to organic matter but also to mineral matter from the residue.

Vertical variation in the organic matter type for each site is shown in Figures 1-3.

\section{Mouth of the Gulf (Fig. 14)}

Holes 474-476 are good examples of the variation in the organic composition of the residue as it relates to the degree of continental influence in sedimentary patterns.

Holes 474 and $474 \mathrm{~A}$. Organic matter consists almost entirely of algal and woody materials; coaly material is present only at the bottom. Algal matter, which is predominant throughout the sedimentary sequence and is mixed with woody material, reaches a maximum in Core $474 \mathrm{~A}-13(282.85 \mathrm{~m})$ and a minimum in Core $474 \mathrm{~A}-37$ $(496.08 \mathrm{~m})$. Using the optical field of the microscope, we calculate that from $95-99 \%$ of the material above Core $474 \mathrm{~A}-13(282.85 \mathrm{~m})$ is algal; that core contains about $50 \%$ algal and $50 \%$ woody material. Beneath Core 474A-13 algal material again constitutes about $95 \%$ but toward the bottom woody material begins to increase, for a composition about $50 \%$ algal, $40 \%$ woody. Thus the marine contribution is greater in the sequence above Core 474A-13 and lower beneath it.

Holes 475 and 476. Marine influence is evident in the predominance of algal material in the residue, but a greater continental influence is apparent in Unit II of Hole 476 and Units II and III of Hole 475, where woody and coaly materials occur in significant quantities, though always subordinate to algal matter. Coaly mate- 


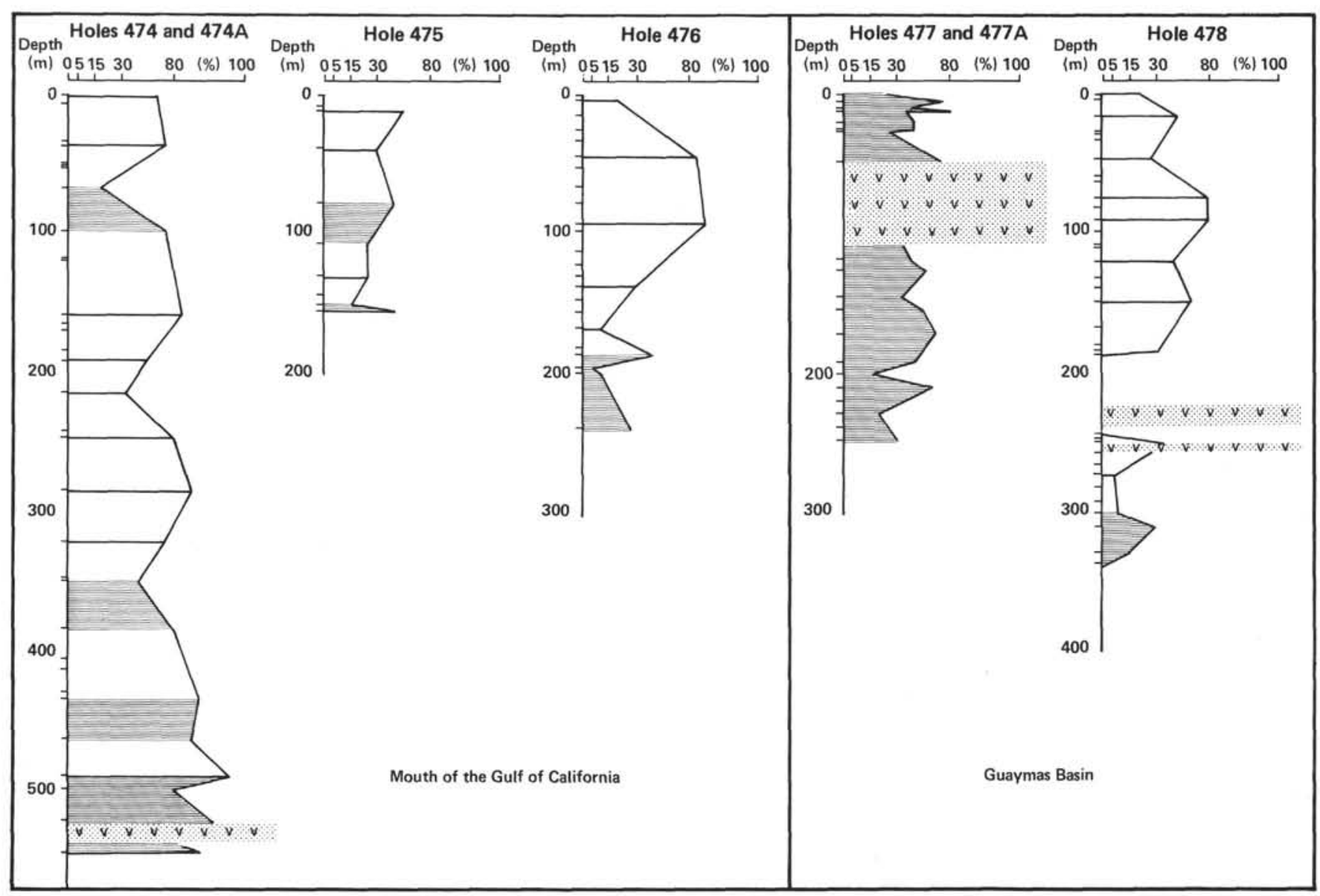

Figure 7. Abundance of inorganic matter, Holes 474-478.

rial, absent in Holes 474 and $474 \mathrm{~A}$, occurs here, certainly derived from oxidation of woody fragments on the continent. In Hole 476 , coaly material is uniformly distributed in Units I-V; in the bottom of the hole, in Unit $\mathrm{V}$, in a conglomerate of metamorphic cobbles maximum values are reached. This material appears to be derived from atmospheric oxidation of woody material, which occurred before the area subsided.

\section{Guaymas Basin (Fig. 15)}

In Holes 477-478, two different types of organic matter occur in the palynological residue.

Hole 477. Unit I, above the dolerite sill, contains predominantly algal with coaly and woody material. Unit II, beneath the sill, contains basically coaly and woody material, with algal material in very low abundance. In this hole, coaly material decreases where woody material is abundant. Coaly material increases in abundance toward the bottom of the hole; there it is the only type of organic matter. We believe that this variation downhole results from the increasingly high hydrothermal influence with increasing depth, which leads to the disappearance of algal and woody materials.

Hole 478. The same variation of organic matter with depth occurs but is not related to the presence of the dolerite sills. In this hole, the continental influence appears in Core 478-11 $(91.09 \mathrm{~m})$, where the maximum value for woody material occurs. Toward the bottom of the hole, beneath the sills, herbaceous matter that represents a more continental environment appears at the base of the sedimentary sequence.

\section{MATURATION INDEX AND COLOR OF ORGANIC MATTER}

The thermal effects of igneous rocks upon organic sediments have attracted the attention of geologists since at least the seventeenth century (Briggs, 1935). The changes that take place in a coal seam adjacent to dikes and sills have been studied by many coal geologists (Eby 1925; Blignaut, 1952; Chakrabarti, 1969; and Feys et al., 1967, among others).

Geologists interested in the effects of igneous intrusions (generally doleritic) on coal beds affirm that metamorphism in the invaded sedimentary beds is confined to heat effects. In almost every case, the intrusions have a well-marked chilled phase in contact with the sedimentary beds into which they have been injected and the sedimentary beds show baking. When sills intrude into a coal bed, the coal is usually carbonized on each side of the intrusion, proportionately to the thickness of the intrusion, though the proportion may vary from onehalf of the thickness of the intrusion to six times as great (Blignaut, 1952). In many cores, the coal in contact with the intrusion is converted into anthracite or natural coke; 


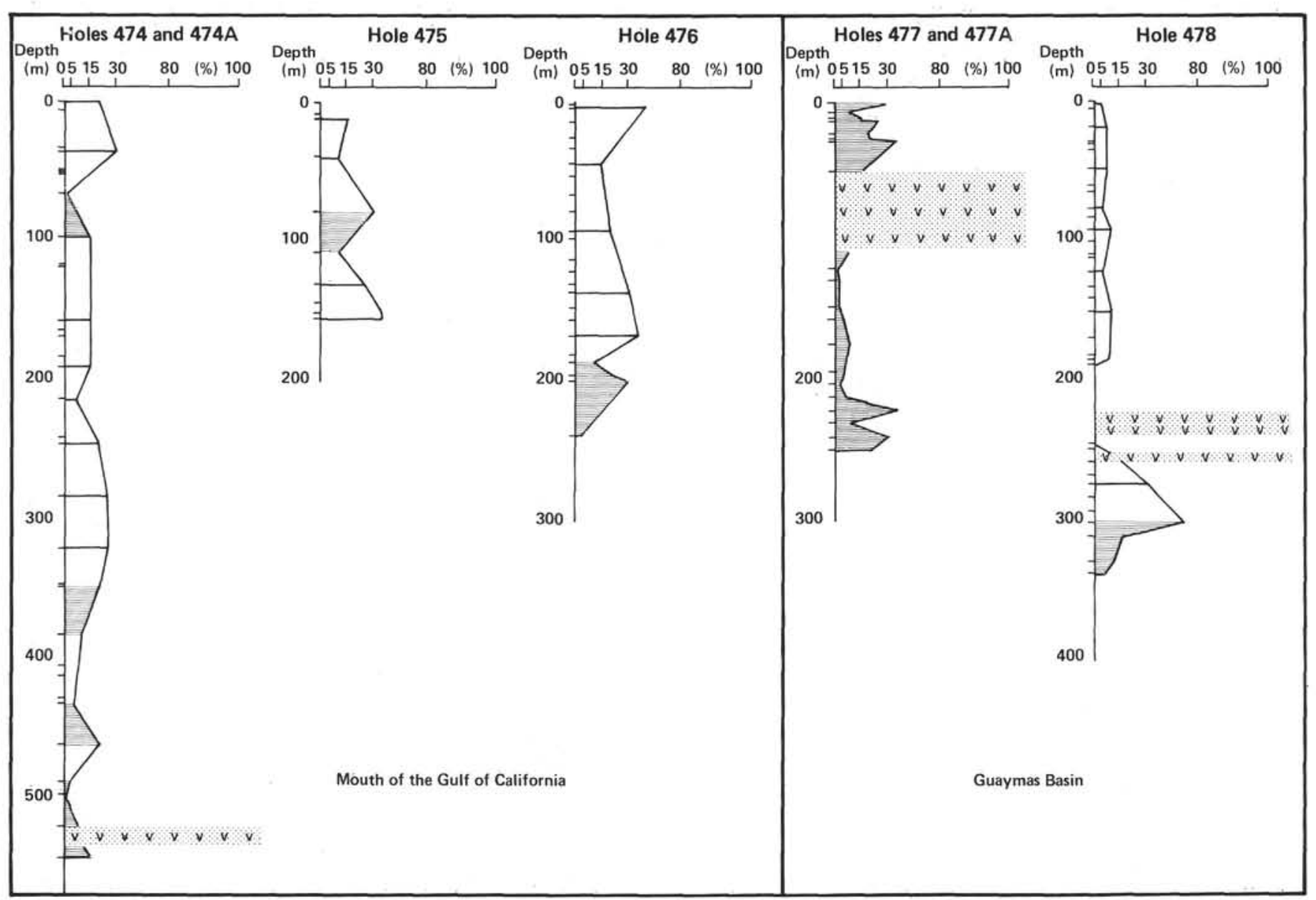

Figure 8. Abundance of organic matter, Holes 474-478.

the coke may even have cavities with graphite (Feys et al., 1967). The intrusion itself may be blanched to a cream-colored rock. The rank of the coal decreases gradually from its contact with the intrusion until it reaches the rank of the normal coal in the basin.

In contacts between intrusions and nonorganic rocks, different effects have been noticed: in sandstones the most visible effect is hard baking, and sometimes the rock becomes quarzitic, in shales the color changes from black or dark-colored to white; and in limestone, the thermal effects produce a fine-grained aggregate of calcite with a little quartz and gray green garnet or a dull, chalky mineral.

Coal close to the intrusions shows effects of devolatilization, disintegration, and infiltration by mineral matter (carbonates). With sills, these effects are more discernible upward than downward from the intrusion, because movement of water is essential in metamorphism.

The regional effects of deep, subsurface, massive igneous intrusions in overlying sedimentary sequences have been studied in detail using optical and geochemical analysis of the organic matter included in the rocks (Leythaeuser et al., 1979). These studies of maturation effects caused by the intrusions in petroleum source beds aim to determine immature, mature, and overmature zones (defined by vitrinite reflectance) and the production of hydrocarbons by igneous heat in these beds.
Optical and geochemical analyses of organic matter from sedimentary rocks are becoming more important in petroleum exploration. These analyses examine organic matter maturation zones that result from geothermal alteration in order to define the depth of the oil window in a petroleum basin. The two most commonly used optical methods for determining thermal alteration of organic material in rocks (Burgess, 1974, 1977) are vitrinite reflectance and organic matter coloration. Dow (1977) showed that vitrinite reflectance is a very useful tool for defining thermal alteration zones in the organic matter of rocks in contact with sills. The present authors have found that the thermally altered zones beneath and above the sill are equal to twice the thickness of the sill.

Vitrinite reflectance has been applied to the analysis of organic matter in sediments and rocks collected during Legs 38 and 42 by Hood et al. (1976) and Kendrick et al. (1978). Unfortunately this method can be applied with confidence only to sediment and rocks in which the vitrinite has a coal rank higher than sub-bituminous coal $\left(\mathrm{R}_{\mathrm{o}}=0.5\right)$; thus it is not used for very shallow, young sediments.

In this chapter we have studied thermal effects of igneous rocks upon organic matter using the organic matter coloration of sediments collected from DSDP holes drilled at the mouth of the Gulf and in the Guaymas Basin (see Figs. 1-3). Determining organic matter colora- 


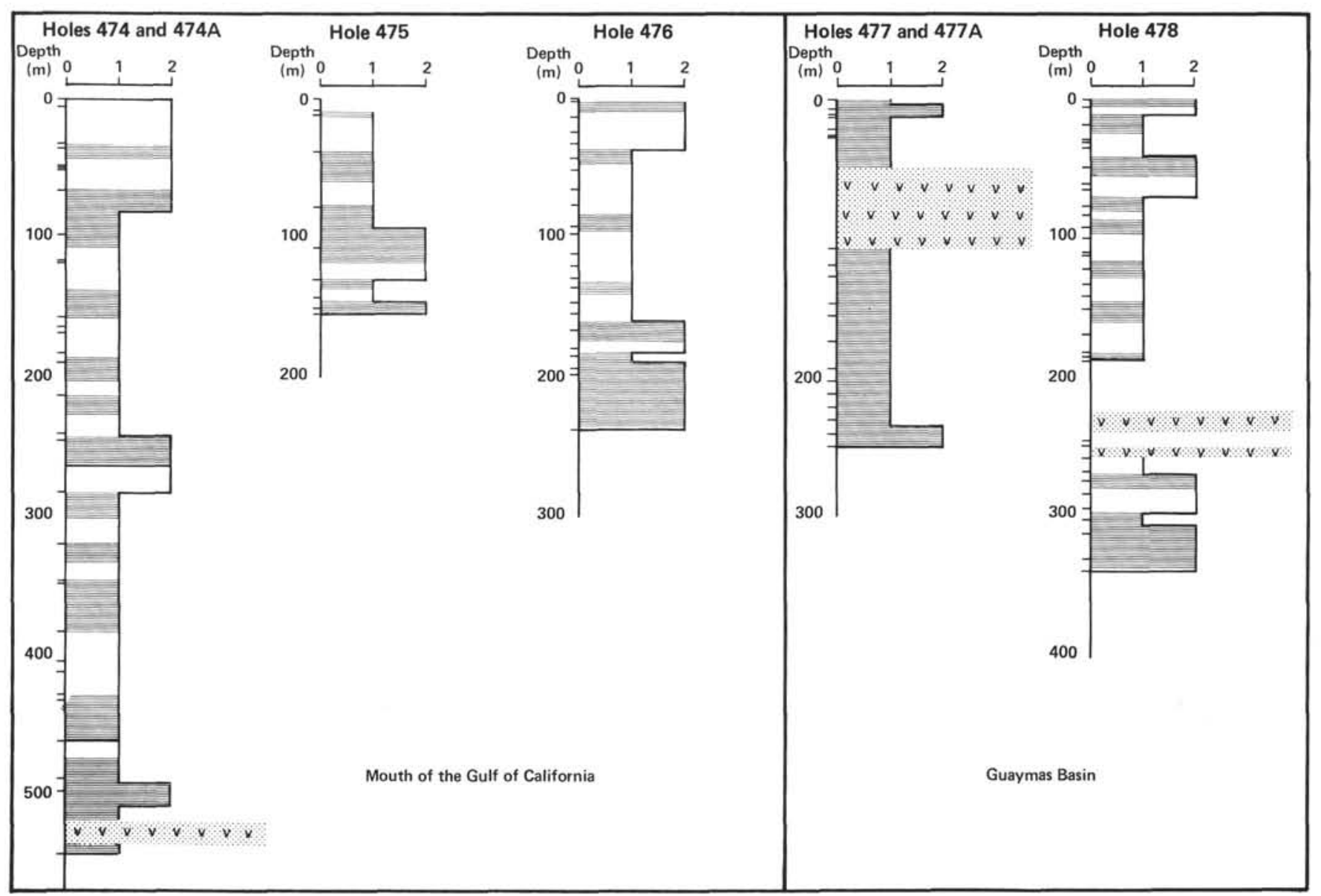

Figure 9. Residue type, Holes 474-478. (For a explanation of the scale, see Fig. 1.)

tion, in particular from continental microfossils, is very important in determining the maturation index that represents thermal effects on the organic matter after sedimentation (Staplin, 1969) because results may be so rapidly obtained, although the method is subjective. Thermal alteration of organic matter can also be determined by optical color identification or by measuring the light absorption of organic matter in a transmitted-light microscope. But sometimes the coloration of the organic matter originates by oxidation in a high-energy marine sedimentary environment and under atmospheric conditions. With both techniques, therefore, it is necessary to differentiate among nonaltered, prealtered or redeposited organic matter.

We have identified 12 grades of maturation of pollen and spores, corresponding to 5 internationally used maturation indices (Table 2).

The actual equivalence of the vitrinite reflectance in oil immersion $\left(R_{0} \%\right)$ with the maximum temperature and maturation index is very difficult to obtain. Many authors (Burgess, 1974; Alpern, 1975; Demaison, 1975; Tissot and Welte, 1978; Bostick, 1979; Hunt, 1979; Heroux, et al., 1979, among others) show different relations between them depending on the age of the analyzed material. In this study the correlation is based on the compilations of Hunt (1979) for kerogen colors and vitrinite reflectance and of Bostick (1979) for vitrinite reflectance and minimum paleotemperatures.
In normal sequences, the grade of maturation and the maturation index based on the color of nonoxidized organic matter increases as the subsurface temperature increases with depth, and the process is irreversible. Thus, in this case cumulative coloration of palynomorphs and other organic matter is an index of thermal metamorphism dependent upon depth, duration of burial, and geothermal gradient in a defined area.

In Figures 1-3 vertical variation in the maturation index is compared with the other characteristics of the residue.

\section{Mouth of the Gulf (Fig. 16)}

In general the grade of maturation here is very low. Only in Hole 476 is there an increase in the maturation of the organic matter at the bottom.

Holes 474 and $474 A$. The general degree of maturation is 2 (index +1 ), but near the top of Core 474-5 $(35.45 \mathrm{~m}$ ) maturation reaches 3 (index -2$)$. The same thing happens near the bottom of the lithological sequence in Cores 474A-36 (486.77 m), 474A-39 (518.65 $\mathrm{m}), 474 \mathrm{~A}-10(527.74 \mathrm{~m})$, and 474A-41 (541.21 m), where the maturation grade (from 3 to 5 ) corresponds to a maturation index of -2 to +2 ; that is, the organic matter is slightly mature. In both cases the lithology shows turbidite sequences with coarse arkosic sediments. In Core 474-5, this slightly higher degree of maturation is possibly due to organic matter oxidized on the continent 


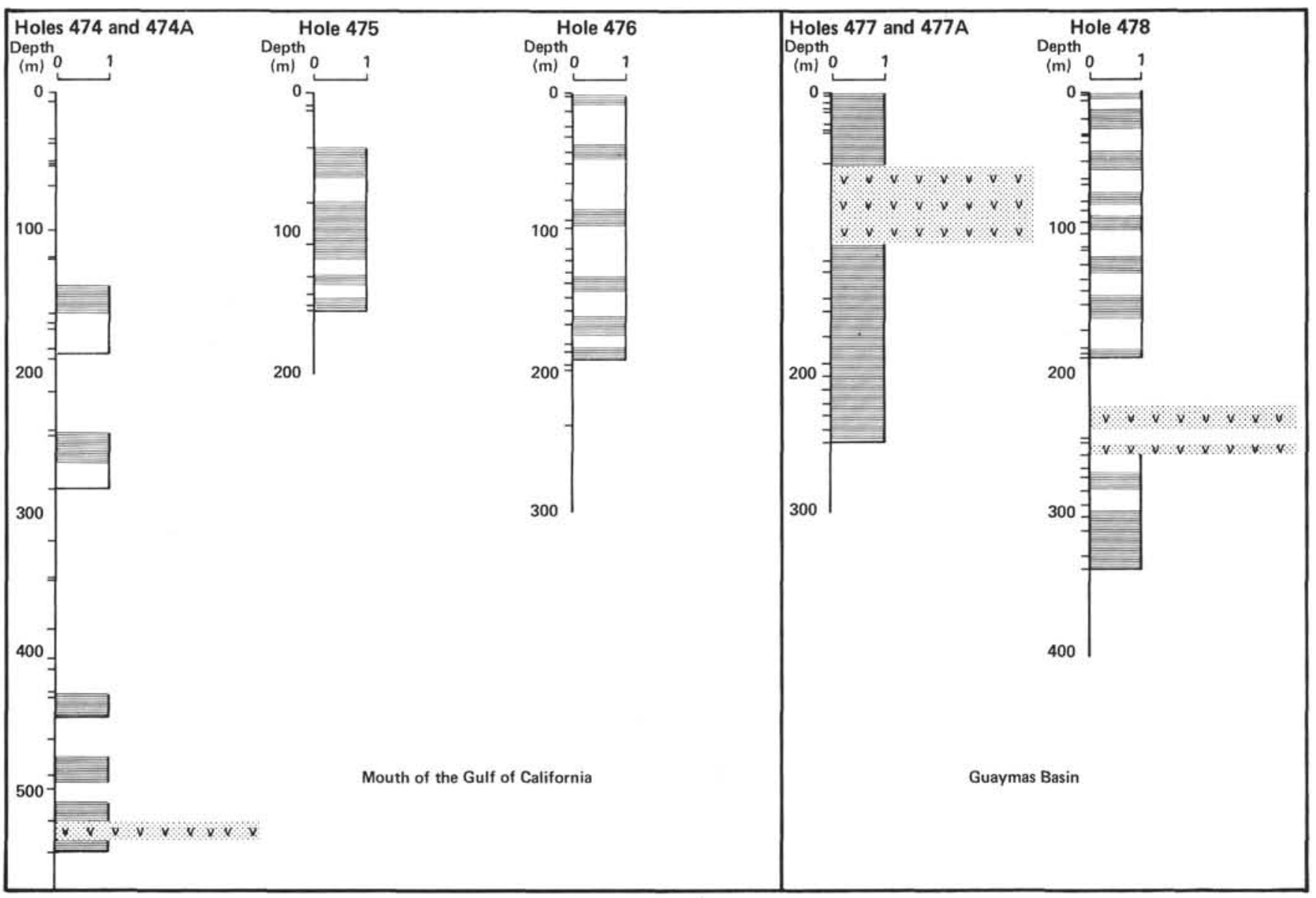

Figure 10. Presence of pyrite, Holes 474-478. ( $\mathrm{O}=$ absent, $1=$ present. $)$

or the continental margin. Toward the bottom (Cores $474 \mathrm{~A}-36,474 \mathrm{~A}-39,474 \mathrm{~A}-40$, and $474 \mathrm{~A}-41$ ) the sediments appear to have been slightly altered thermally by the olivine-dolerite sills present there. The maximum degree of 6 (index +2 ) is reached in Core 474A-36, 33.23 meters above the contact with the dolerite sill, at the base of a turbidite sequence. We believe that this degree of maturation is caused by organic matter oxidized on the continent, because in Core 474A-37, about 10 meters below, the maturation degree is only 2 ; it then increases downhole to 3 in Cores $474 \mathrm{~A}-39$ and $474 \mathrm{~A}-40$. The samples analyzed from these last two cores were collected at about $85 \mathrm{~cm}$ above and $60 \mathrm{~cm}$ beneath the glassy contact with the dolerite unit from 520 to 527 meters depth in Hole 474A. In this case, the maturation degree of 3 must be due to heat flow from the sill.

Hole 475. The maturation degree of 2 is uniform from Cores $475-2(11.51 \mathrm{~m})$ to $475-15(135.67 \mathrm{~m})$. In Core $475-17(150.25 \mathrm{~m})$ the maturation degree of 3 is caused by previous oxidation of continental material.

Hole 476. This hole contained the highest degree of maturation for all sediments drilled in the mouth of the Gulf. Units I-III show decreasing degrees from 4 to 2 (in Core 476-20,185.10 m) that nearly parallel the variation of the values for coaly organic matter. In this case we consider that this maturation is not the result of thermal effects but of the oxidation of organic matter from the continent. This is more evident in Unit V, where the degree of maturation reaches 9 in Core 476-26 (237.97 $\mathrm{m})$, in a conglomerate of metamorphic cobbles with illitic clay, above weathered granite-that is, rocks of continental origin-exposed to intensive oxidation, with abundant, coaly organic matter.

\section{Guaymas Basin (Fig. 16)}

Degree of maturation is higher here than in the mouth of the Gulf and the maturation colors of organic matter have two different origins: (1) the very high heat flow values and hydrothermal activity in the Guaymas Basin, near the spreading axes; (2) a very thick sedimentary sequence of terrigenous turbidites (possibly from the continent and from the Baja California Peninsula) deposited at a very high rate of sedimentation $(0.65 \mathrm{~cm} / \mathrm{y}$.) at Site 478 .

Holes 477 and $477 A$. Degree of maturation increases from the top to the bottom of the sedimentary sequence. In Unit I the degree of maturation ranges from 2 to 5 (i.e., a maturation index of $+1-+2$ ). In Unit II it ranges from 6 to 9 (a maturation index of $-3--4$ ). A very thick dolerite layer considered to be a sill occurs between Units I and II. At the top of Unit I (Cores 477-2, $5.77 \mathrm{~m}$, and $477-3,10.57 \mathrm{~m}$ ) the degree of maturation is 4 ; it decreases to 2 in Core $4(20.79 \mathrm{~m})$ and then increases to 5 in Core $477-7$ ( $49.04 \mathrm{~m})$, about 9 meters 


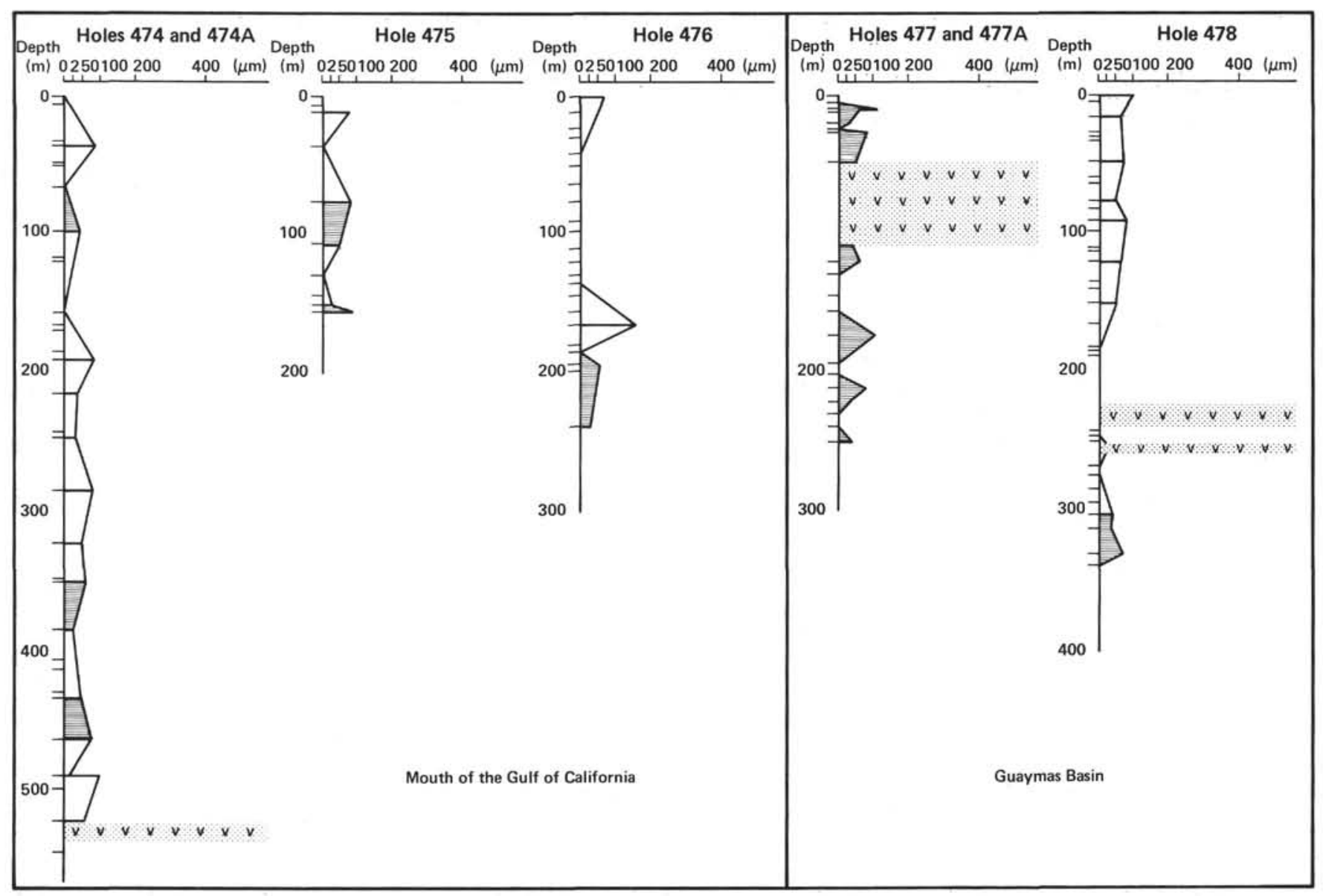

Figure 11. Size of terrigenous crystals, Holes 474-478.

above the sill. The high degree of maturation at the top of Unit $I$ is probably due to oxidized organic terrigenous material (deposited by turbidites) from the continent. By contrast, the degrees of maturation increase from 6 to 9 from Cores $477-15(105.52 \mathrm{~m})$ to $477-19(145.46 \mathrm{~m})$. Downhole from Core 477-19, the degree of maturation reaches a maximum value of 9 , with some values of 3 in two horizons in Cores 477A-5 $(192.22 \mathrm{~m})$ and 477A-9 $(229.16 \mathrm{~m})$. Note that the maturation curve is very similar to that of the bulk density log and also to the temperature curve of readings made after driling. The low degrees of maturation from Cores 477A-5 (sandy silt) and 477A-9 (breccia of silty sand and sandstone) are related to their low density.

The presence of the very low degrees of maturation of organic matter in Cores 477A-5 and 477A-9, in a sequence with generally very high values, appears anomalous, for in normal sedimentary sequences, maturation increases progressively from top to bottom, and coalification of organic matter is progressive, cumulative, and irreversible because of the effects of time and increasing temperature with depth. From Cores 477-15 (105.52 m) to $477-23(191.00 \mathrm{~m})$, the degree of maturation increases from 6 to 9 . In this interval the palynological residue displays a very low abundance of inorganic matter and very high abundance of organic matter. The lithology of this interval is also unlike that of the lower interval of
Unit II from Cores 477A-5 $(192.22 \mathrm{~m})$ to $477 \mathrm{~A}-11$ $(248.40 \mathrm{~m})$, because it is composed of finer sediments. This change of lithology and abundance of organic and inorganic matter is also related to very high particle sizes of organic and inorganic materials. Perhaps because of variations in sediment compaction, these two units transmitted heat differently.

Another anomaly is related to the presence of the dolerite layer, which apparently did not substantially affect the maturation of the organic matter. Usually, organic matter in sediments or rocks that are above or beneath a thick, intrusive igneous body have very high degrees of maturation, which decrease progressively upward and downward from these contacts. In Holes 477 and $477 \mathrm{~A}$, however, the organic matter in sediments above and below the igneous layer have degrees of maturation of 5 (index +2 ) and 6 (index -3 ). This is very unexpected, because their degrees of maturation should be very high.

Perhaps the explanation lies in the fact that the dolerite layer is actually a basalt layer deposited above Unit II; the basalt thermally altered only the upper part of the sediments to a degree of maturation of 6 ; the deposition of Unit I occurred later. The igneous layer formed a closed thermal system in which sediments were thermally altered from the top-because of the diffusion of temperature from the igneous layer during cool- 


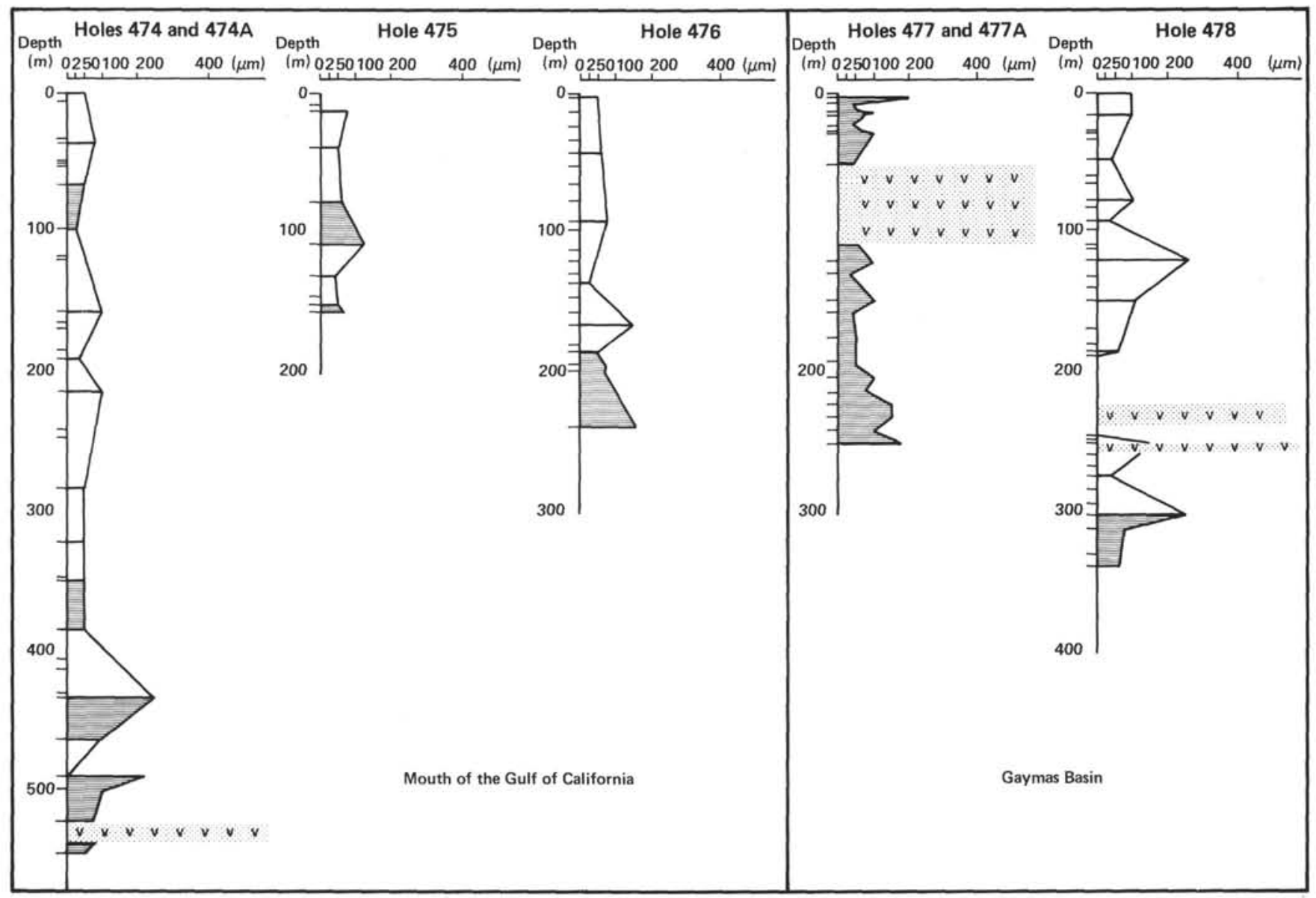

Figure 12. Size of mineral matter, Holes 474-478.

ing - and from the bottom-by diffusion of heat from the oceanic crust. Thereafter the closed system stabilized, and temperature from the oceanic crust began to behave normally near the top of the lithologic sequence. Thus the igneous layer transmitted only the heat flow from the oceanic crust upward to the sediments of Unit I, resulting in normally decreasing values of maturation in an upward direction. To date, no conclusive finding has been possible. Perhaps a more detailed optical and geochemical analysis of organic matter will provide a satisfactory explanation.

Hole 478. The maturation of organic matter followed a different path here. In Unit I, the degree of maturation ranges between 3 and 5 . Degree 5 is reached in Core 478-9 $(75.67 \mathrm{~m})$, where the abundance of algal material is very low and that of coaly and woody materials high. In this same core, the lithology shows thin turbidite sequences with basal sands in Section 478-9-4. These carbonate sediments are probably terrestrial and marginal in origin and contain oxidized organic materials. In samples from Cores $478-1(0.35 \mathrm{~m})$ to $478-17$ (149.16 $\mathrm{m})$, crystals and crystalline debris of continental origin range from 50 to $100 \mu \mathrm{m}$. The high abundance of woody material downhole in Core 478-11 $(91.09 \mathrm{~m})$ could explain the uniformly high values in the degree of maturation above the dolerite sills. As in Hole 474, we have no evidence of high thermal alteration of organic matter above the sill from 221 to 231.5 meters. In contrast, or- ganic matter clearly increases below this sill and above the sill from 253.5 to 258.0 meters. In Unit II, the degree of maturation increases from the top to the bottom, where it reaches a value of 9 (index -4) just above the dolerite intrusion. In this case, it seems that maturation is due to the heat flow from the intrusions between 345.5 and 464.0 meters.

\section{SUMMARY AND CONCLUSIONS}

Optical analysis of the total and the refractory palynological residues of sediments from holes drilled in the mouth of the Gulf of California and the Guaymas Basin provides evidence about sedimentology, type and origin of the organic matter, heat flow effects, and the effects of intrusions on organic matter. To summarize our conclusions:

1) Abundance of the palynological residue in the samples is related to their lithology and their geographical location vis-à-vis the coastline. The highest values were found in samples from the mouth of the Gulf in hemipelagic diatomaceous and nannofossil ooze and mud; the lowest in samples from the Guaymas Basin, in coarse sediments, arkoses and sandy turbidites, particularly in hydrothermally altered terrigenous turbidites beneath the dolerite sills.

2) The color of the palynological residue depends on the relative abundance of organic and mineral matter in it. The highest values are observed for samples of hemi- 


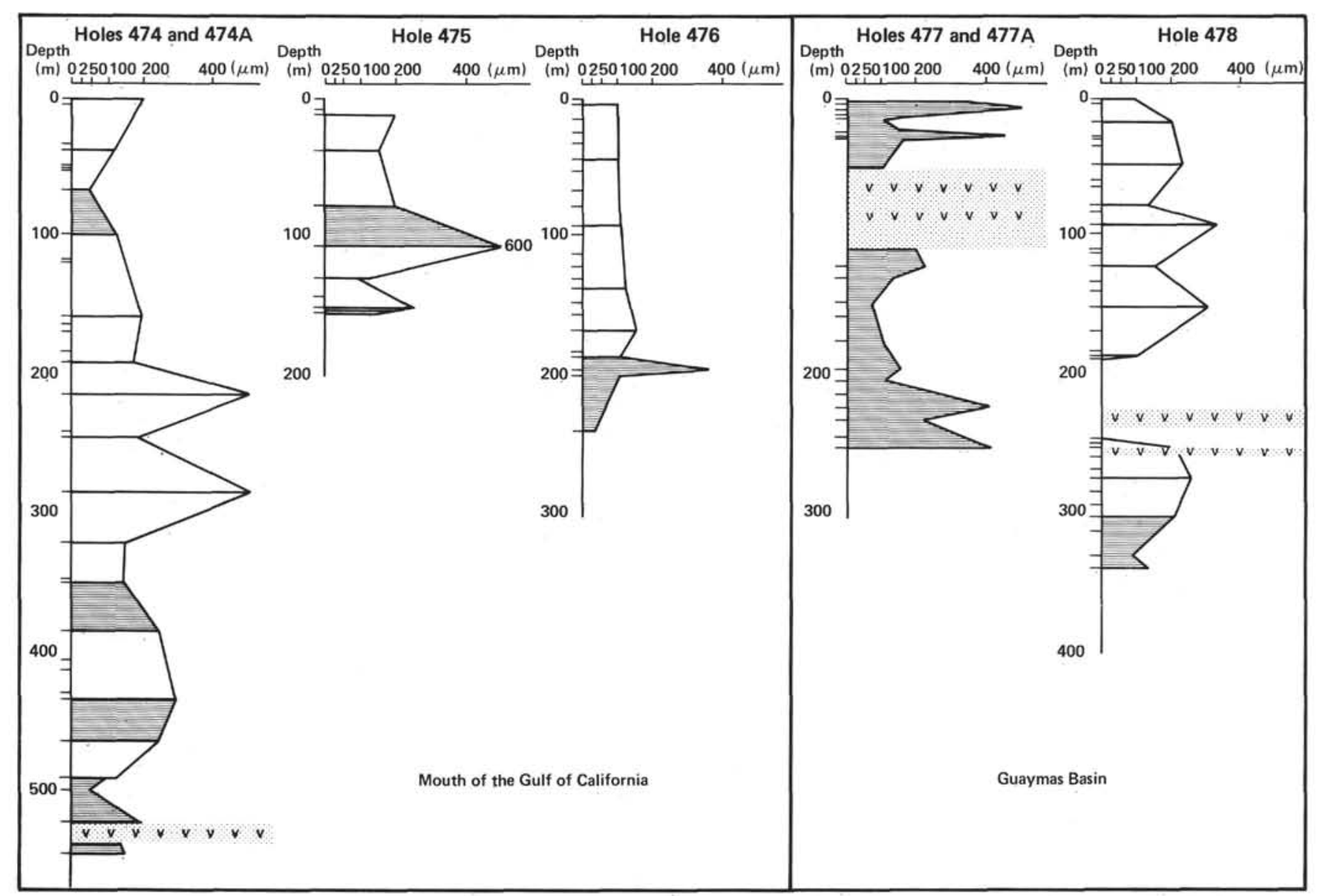

Figure 13. Size of organic matter, Holes 474-478.

pelagic muds and silty claystone and clayey siltstone materials from the Gulf. A light brown color appears there in coarse sediments and glauconitic materials. In the Guaymas Basin, a black color seems to be related to the presence of coaly organic debris resulting from the influence of a high geothermal gradient and heat flow from the intrusions. Thus in the data there exists nearly a direct correlation of color with the vertical variation in the graphs, reflecting the presence of coaly matter with a high maturation index.

3) The alcohol-glycerin solution in samples from the mouth of the Gulf is colorless from top to bottom in Holes 474-475; in Hole 476, it is highly colored toward the bottom in samples of glauconitic sand with phosphorite and pyrite, just above a laminated sapropelic claystone with a petroliferous odor. In the Guaymas Basin, the highest colors appear near the contacts with the dolerite sills.

4) In the mouth of the Gulf, the maximum abundances of inorganic matter are present in diatomaceous muds, silty claystone, and clayey siltstone and sometimes in hemipelagic muds. The minimum values occur in coarse sediments like coarse arkose. In the Guaymas Basin, the maximum values are found in the sedimentary sequences above the sills and in hydrothermal sediments with epidote.
5) The vertical variation in the abundance of mineral and organic matter depicted in the graphs is almost parallel. The principal variation in the abundance of organic matter is its increasing quantity as we move from a continental toward an open marine environment.

6) In the mouth of the Gulf there are very clear differences in the nature of the palynological residue. A regular type of residue is directly related to a quiet, very low energy environment; an irregular type of residue corresponds to a high-energy sedimentary environment. Regular residues are found in hemipelagic diatomaceous muds and in redeposited ooze and nannofossil marls, diatomaceous muds, and organic claystone. Irregular types are present in samples composed of turbidites with arkosic sands and clayey siltstone. In Hole $477 \mathrm{~A}$ in the Guaymas Basin, the irregular type predominated in the unit beneath the dolerite sill; it is related to woody and coaly organic matter.

7) Pyrite is found in samples where woody organic matter is predominant and is also abundant in hydrothermally altered sediments beneath the dolerite sills. In the Guaymas Basin holes, this mineral is present in all analyzed samples from the sedimentary sequence.

8) The maximum size of terrigenous crystals and crystalline debris occurred in turbidites and coarse sandy sediments. In sites from the Guaymas Basin the terrig- 


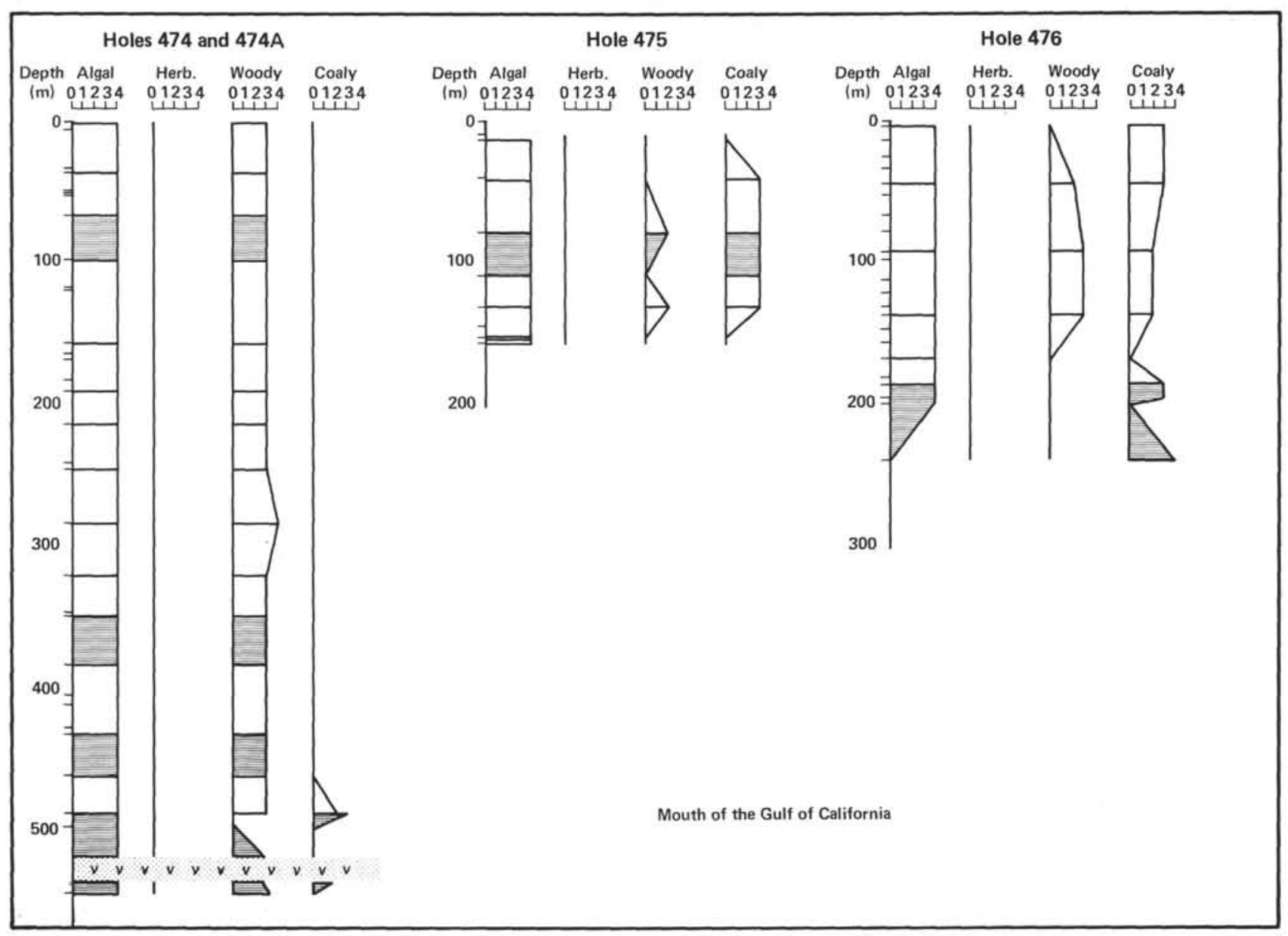

Figure 14. Type of organic matter, Holes 474-476.

enous material is uniformly present only in the turbidite sequence of Unit I, above the dolerite sills.

9) Mineral matter other than crystalline terrigenous remains is abundant in carbonate sediments and in some calcareous silty claystones and clayey siltstones. In holes at the mouth of the Gulf, the increasing size of this mineral matter parallels the increasing grain size of the crystalline terrigenous debris. In the Guaymas Basin, maximum size and abundance of this mineral matter is reached in dolomite, anhydrite, and calcareous layers. In some samples this material is possibly derived from the nannofossil and calcareous cement of the sediment.

10) The maximum size of the organic matter in the holes from the mouth of the Gulf and Guaymas Basin is observed for woody and coaly debris. The size of the organic matter increases from the top to the bottom of the holes, indicating a gradual increase in the influence of the marine environment toward the top of the sequences.

11) The type of organic matter in the sedimentary sequences from the mouth of the Gulf shows clear differences in sedimentary environments. In general, woody and coaly materials are more abundant toward the bottom of the sedimentary sequences and at sites near the coastline. In this region, coaly material seems to have originated by atmospheric oxidation of woody material from the continent. Toward the top of the sequences, there is an increase in algal material, corresponding to a more marine environment. In the Guaymas Basin, the type of organic matter reveals two different sedimentary units. In Unit I, above the sill in Hole 477A, the organic matter is dominantly algal; beneath the sill, it is basically coaly and woody. In this site coaly material increases in abundance downhole, owing to the increasing hydrothermal influence with depth that transforms woody and algal material into coaly material; in this case, the coaly material comes basically from woody fragments deposited at the bottom of the sedimentary sequence. In Hole 478 the same variation of organic matter with increasing depth appears, though it is not related to the presence of the dolerite sills; continental influence is evident beneath the sills, where herbaceous matter is abundant at the base of the sequence.

12) At the mouth of the Gulf, the degree of maturation is very low. Only in Hole 476 does maturation of the organic matter increase near the bottom, as a result of continental oxidation of the organic matter. In the Guaymas Basin the degree of maturation is higher than at the mouth of the Gulf, and maturation of the organic matter has two different origins: hydrothermal activity and continental oxidation of the organic matter deposited in the basin. In Holes 477 and $477 \mathrm{~A}$ the degree of 


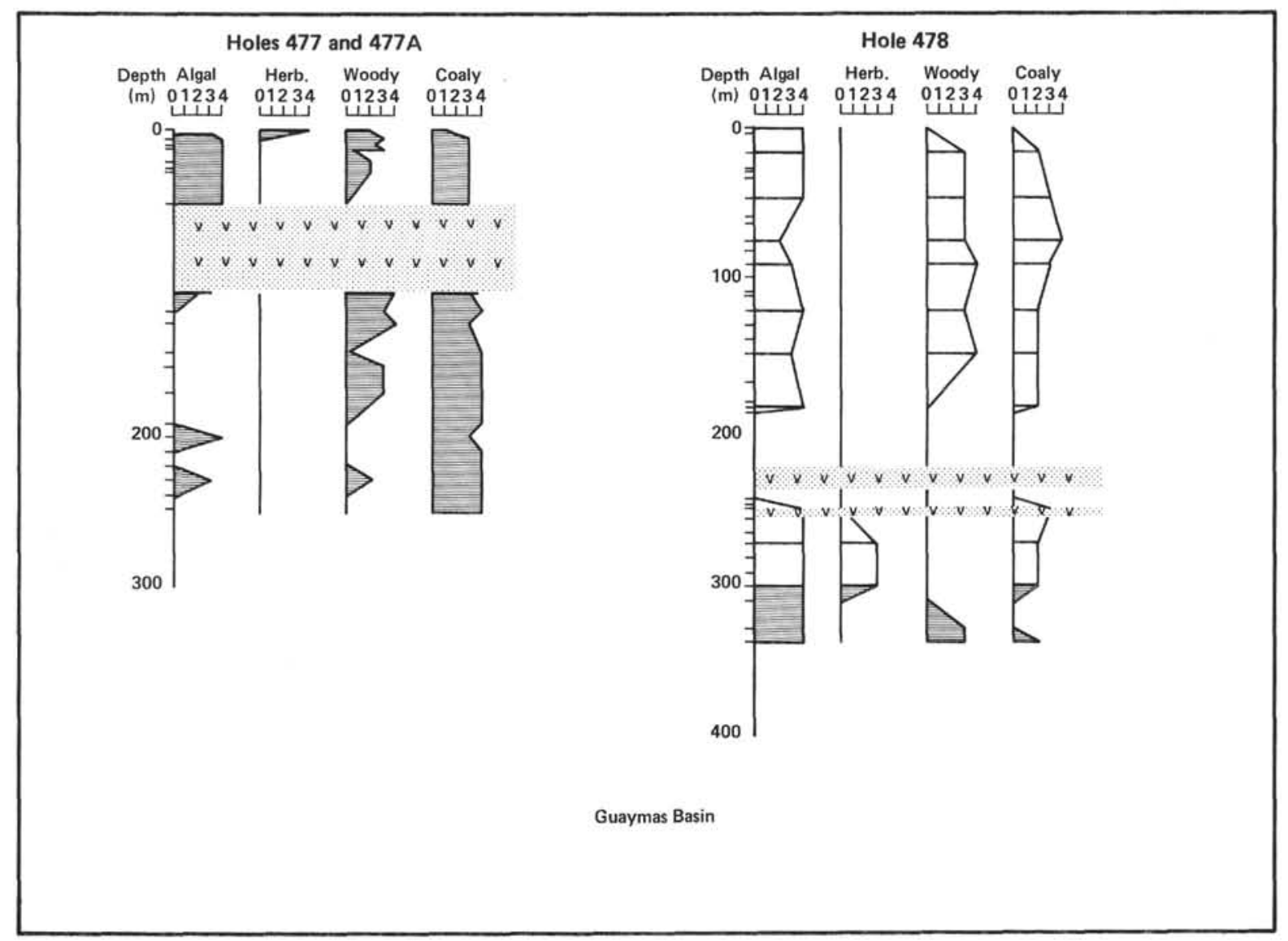

Figure 15. Type of organic matter, Holes 477-478.

Table 2. Scale of maturation degrees and index based on the color of the organic particles.

\begin{tabular}{|c|c|c|c|c|}
\hline Degrees & Index & Color & $\begin{array}{l}\text { Approximate Equivalent } \\
\text { of Vitrinite Reflectance } \\
\text { in Oil (Hunt, 1979) }\end{array}$ & $\begin{array}{c}\text { Approximate } \\
\text { Paleotemperature } \\
\text { (Bostick, 1979) }\end{array}$ \\
\hline 1 & 1 & $\begin{array}{l}\text { colorless or } \\
\text { light yellow }\end{array}$ & & \multirow{4}{*}{$100^{\circ} \mathrm{C}$} \\
\hline 2 & +1 & yellowish green & & \\
\hline 3 & -2 & yellow & & \\
\hline 4 & 2 & yellow-orange & 0.5 & \\
\hline 5 & +2 & orange-brown & \multirow[t]{2}{*}{1.0} & \multirow{2}{*}{$180^{\circ} \mathrm{C}$} \\
\hline 6 & $\begin{array}{r}-3 \\
3\end{array}$ & $\begin{array}{l}\text { light brown } \\
\text { brown }\end{array}$ & & \\
\hline & & & \multirow[t]{2}{*}{2.0} & \multirow[t]{2}{*}{$237^{\circ} \mathrm{C}$} \\
\hline $\begin{array}{l}8 \\
9\end{array}$ & $\begin{array}{l}+3 \\
+4\end{array}$ & dark brown & & \\
\hline & -4 & brownish black & \multirow[t]{4}{*}{4.0} & \\
\hline 10 & 4 & black & & \\
\hline 11 & +4 & $\begin{array}{l}\text { black } \\
\text { (corroded, high } \\
\text { alteration) }\end{array}$ & & \\
\hline 12 & 5 & $\begin{array}{l}\text { black } \\
\text { (unrecognizable) }\end{array}$ & & \\
\hline
\end{tabular}

maturation increases from the top to the bottom of the sedimentary sequence. Unit I shows a degree of maturation that ranges from 2 to 4 (index +1 to +2 ) and Unit II a range from 6 to 9 (index -3 to -4 ). The high values at the top of Unit I are probably due to oxidized organic terrigenous material from the continent that has been deposited by turbidites. The maturation degree of 5 (index +2 ) immediately above the sill and the increas- ing degree of maturation from 6 to 9 downhole from the sill are probably basically caused by the hydrothermal effect-the diffusion of heat from the oceanic crust and the cooling of the dolerite sill. In Hole 478, maturation of the organic matter has proceeded differently. We have no evidence of high thermal alteration above the sills, but beneath them the degree of maturation increases gradually to 9 , just above the dolerite intrusions at the bottom of the hole. It appears that maturation is caused by the heat flow from these intrusions.

\section{ACKNOWLEDGMENTS}

The authors wish to express their gratitude to the co-chief scientists of the expedition, Dr. David G. Moore and Dr. Joseph Curray, for the opportunity to undertake this study, and to the Instituto Mexicano del Petróleo for granting permission and providing the facilities to conduct this work.

The manuscript was reviewed by Dr. Kerry Kelts and Dr. Bernd R. T. Simoneit; their assistance is gratefully acknowledged.

\section{REFERENCES}

Alpern, B., 1975. Introduction to "Indices optiques de la matiere organique des sédiments, relations avec la paléotemperature et le potentiel petrolier." In Alpern, B. (Ed.), Pétrographie Organique et Potentiel Pétrolier: Paris (CNRS), pp. 191-194.

Blignaut, J. J. G., 1952. Field relationships of the dolerite intrusions in the Natal coalfieds. Trans. Geol. Soc. S. Afr., 55:19-31.

Bostick, N. H., 1979. Microscopic measurement of the level of catagenesis of solid organic matter in sedimentary rocks to aid exploration for petroleum and to determine former burial temperatures: A review. In Scholk, P. A., and Schlager, P. R. (Eds.), Aspects of 
Diagenesis: Society of Economic Paleontologists and Mineralogists Special Publication 26:17-43.

Briggs, H., 1935. Alteration of coal-seams in the vicinity of igneous intrusions and associated problems. Trans. Inst. Min. Eng., 89: 187-211.

Burgess, J., 1974. Syllabus: Symposium on thermal maturation of organic material as related to hydrocarbon generation and migration. Proc. 8th Ann. Meeting Am. Assoc. Strat. Palynol., pp. $1-26$.

1977. Historical review and method of determining thermal alteration of organic materials. Palynology, 1:1-8.

Chakrabarti, A. K., 1969. On the effects of igneous intrusion on a few coal seams of the Jharia coalfield, Bihar, India. Econ. Geol., 64: 319-324.

Combaz, A., 1964. Les palynofacies. Rev. Micropaleontol., 7: 205-218.

Cross, A. T., Thompson, G. G., and Zaitzeff, J. R., 1966. Source and distribution of palynomorphs in bottom sediments, southern part of Gulf of California. Mar. Geol., 4:467-524.

Demaison, G. J., 1975. Relationships of coal rank to paleotemperatures in sedimentary rocks. In Alpern, B. (Ed.), Petrographie Organique et Potentiel Petrolier: Paris (CNRS), pp. 217-224.

Dow, W. G., 1977. Kerogen studies and geological interpretations. J. Geochem. Explor., 7:77-79.

Eby, J. B., 1925. Contact metamorphism of some Colorado coals by intrusives. Trans. Am. Inst. Min. Metall. Eng., 61:246-252.

Feys, R., Geffroy, J., and Vetter, P., 1967. Un cas nouveau de graphitisation du charbon par une intrusion eruptive a Cali (Colombie). Ann. Soc. Geol. Nord., 87:145-150.

Heroux, Y., Chagnon, A., and Bertrand, R., 1979. Compilation and correlation of major thermal maturation indicators. Am. Assoc. Pet. Geol. Bull., 63:2128-2144.

Hood, A., Castaño, J. R., and Kendrick, J. W., 1976. Petroleum-generating potential and thermal history of DSDP Leg 38 sediments. In Talwani, M., Udintsev, G., et al., Init. Repts. DSDP, 38: Washington (U.S. Govt. Printing Office), 801-803.

Hunt, J. M., 1979. Petroleum Geochemistry and Geology: San Francisco (W. H. Freeman)

Kendrick, J. W., Hood, A., and Castaño, J. R., 1978. Petroleumgenerating potential of sediments from the eastern Mediterranean and Black seas. In Ross, D. A., Neprochnov, Y. P., et al., Init. Repts. DSDP, 42, Pt. 2: Washington (U.S. Govt. Printing Office), 729-735.

Leythaeuser, D., Altebaumer, F. J., and Schaefer, R. G., 1979. Effect of an igneous intrusion on organic matter in Lower Jurassic shales from NW Germany. Inst. Pet. Org. Geochem. Interim Report No. 502579:1-15.

Manum, S. B., 1976. Dinocysts in Tertiary Norwegian-Greenland Sea sediments (Deep Sea Drilling Project, Leg 38), with observations on palynomorphs and palynodebris in relation to environment. In Talwani, M., Udintsev, G., et al., Init. Repts. DSDP, 38: Washington (U.S. Govt. Printing Office), 897-920.

Müller, J., 1959. Palynology of Recent Orinoco Delta and shelf sediments: Reports of the Orinoco Shelf Expedition. Micropaleontology, 5:1-32.

Rueda-Gaxiola, J., 1975. Estudio de los constituyentes orgánicos e inorgánicos de las formaciones jurásicas Huayacocotla y Rosario del E de México y su relación con la paleogeografia, sedimentación, generación y entrampamiento de hidrocarburos [Unpublished report]. Inst. Mex. Pet. Proyecto C-3019.

1978. Estudio de la maduración de la materia orgánica de los sedimentos de la cuenca de Sebastián Vizcaino, Baja California [Unpublished report]. Inst. Mex. Pet. Proyecto C-1045 (primera parte).

Rueda-Gaxiola, J., de Castro, M. T., Hernández, O., and Collado, M., 1977. Estudio palinológico, geoquímico y petrográfico de los núcleos 10 y 11 del pozo Xoconoxtle No. 1 en et Altiplano Mexicano. Rev. Inst. Mex. Pet., 9:6-19.

Rueda-Gaxiola, J., Sandoval, S., Morales, J., and Dueñas M. A., 1980. Estudio palinoestratigráfico, mineralógico, de geoquímica inorgánica y de evaluación económica-petrolera de las rocas de la cuenca de Sebastián Vizcaino, Baja California [Unpublished report]. Inst. Mex. Pet. Proyecto C-1045 (segunda parte).

Staplin, F. L., 1969. Sedimentary organic matter, organic metamorphism, and oil and gas occurrence. Bull. Can. Pet. Geol., 17:47-66.

Tissot, B., and Welte, D. H., 1978. Petroleum Formation and Occurrence: Berlin (Springer-Verlag).

Traverse, A., and Ginsburg, R. N., 1966. Palynology of the surface sediments of Great Bahama Bank, as related to water movement and sedimentation. Mar. Geol., 4:417-459. 


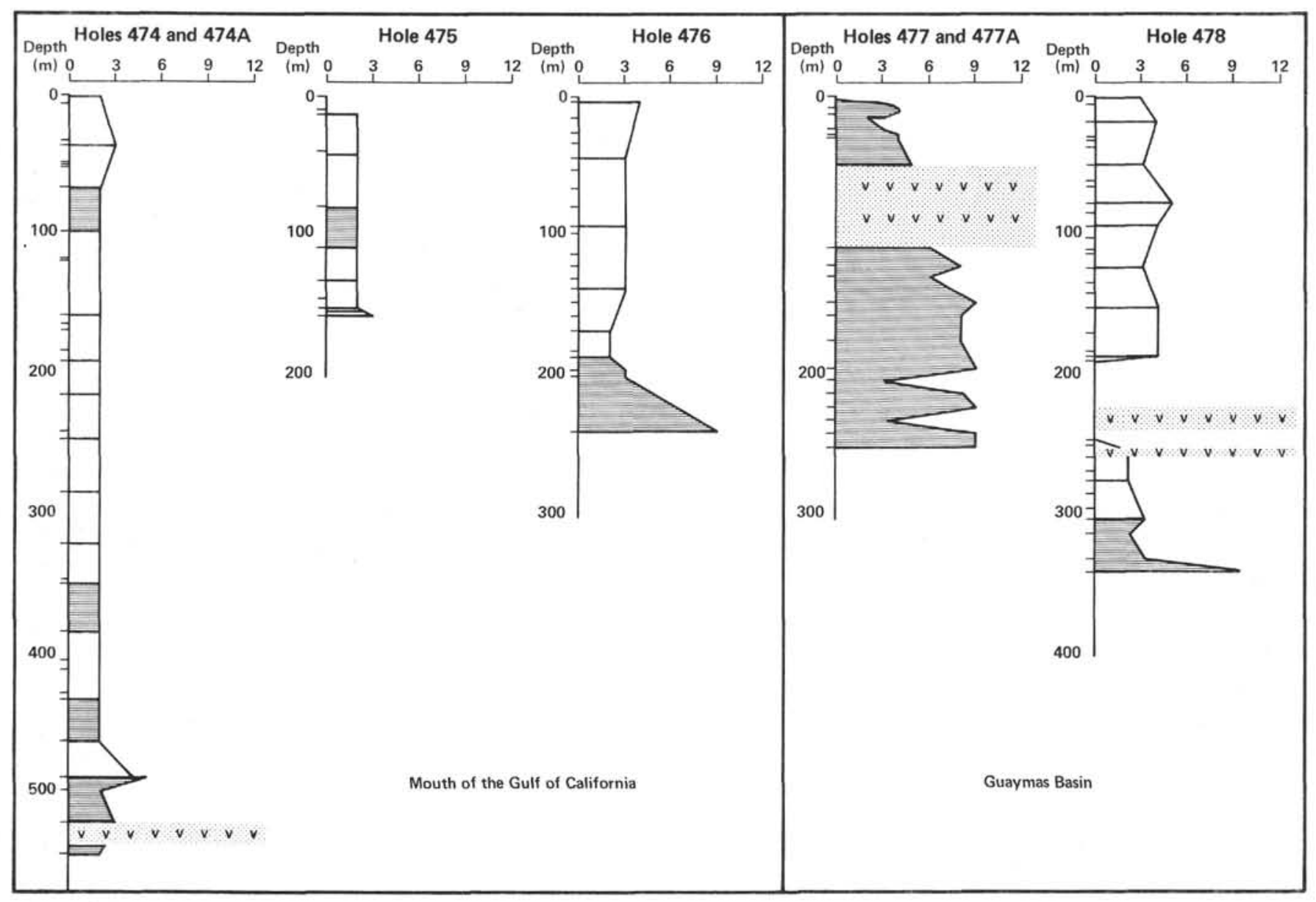

Figure 16. Degree of maturation, Holes 474-478. (For grades of maturation, see Table 2.) 